\title{
HUBUNGAN KEMAMPUAN KOGNITIF, NILAI BUDAYA, GAYA HIDUP DENGAN EMPATI LINGKUNGAN PADA MASYARAKAT WILAYAH SUNGAI PEMBUANGAN LIMBAH BATIK Survei pada Masyarakat Kota Batik Surakarta
}

PEDUK RINTAYATI

Dosen Universitas Negeri Surakarta (UNS)

Abstract

The objective of this research is to study the relationship between cognitive ability, cultural value, and lifestyle with the environment empathy towards the society in the batik waste disposal area.

The research was conducted in the community of batik waste disposal area. The sample was taken by using random sampling technique.

The data for the environmental empathy, cognitive ability, value of culture, and lifestyle were gathered by using questionnaire. The data obtained was analyzed by using regression, simple correlation, multiple correlation, and partial correlation.

The result of the study showed that: (1) there was a positive correlation between the cognitive ability with environmental empathy; (2) the was a positive correlation between the value of culture with the environmental empathy; (3) there was a positive correlation between lifestyle with the environmental empathy; (4) there was a positive correlation between cognitive ability, value of culture, and lifestyle with the environmental study.

It can be concluded that cognitive ability, value of culture, and lifestyle can increase the envir ${ }^{i}$ onmental empathy.

\section{PENDAHULUAN}

\section{A. Latar Belakang Masalah}

Masalah lingkungan hidup selalu jadi bahan perbincangan yang tidak pernah habis dibicarakan di setiap negara yang berkaitan erat dengan pencemaran lingkungan. Pencemaran yang terjadi juga semakin terasa mengganggu kehidupan masyarakat sejak berkembangnya manufaktur pada awal tahun tujuh puluhan. Limbah hasil proses industri, buangan aktifitas manusia dalam memenuhi kebutuhan hidup, buangan sisa-sisa pemotongan hewan, limbah pasar merupakan pencemaran lingkungan.

Lingkungan merupakan kombinasi antara kondisi fisik yang mencakup keadaan sumber daya alam seperti tanah, air, energi surya, mineral, serta flora dan fauna yang tumbuh di atas tanah maupun di dalam lautan, dengan kelembagaan yang meliputi ciptaan manusia seperti keputusan bagaimana menggunakan lingkungan fisik tersebut. Lingkungan terdiri dari komponen abiotik dan biotik.

Komponen abiotik adalah segala yang tidak bernyawa seperti tanah, udara, air, iklim, kelembaban, cahaya, bunyi. Sedangkan komponen biotik adalah segala sesuatu yang bernyawa seperti tumbuhan, hewan, manusia dan mikroorganisme (virus dan bakteri) (http://id.wikipedia.org/wiki/).

Pencemaran akibat dari racun kimia di lingkungan menjadi ancaman sangat penting dalam kehidupan manusia pada polusi udara, air dan tanah.

Pencemaran air akan berdampak terhadap limgkungan tanah sehingga akan memberikan dampak terhadap ekosistem tanah. Perubahan kimiawi tanah yang radikal dapat timbul dari adanya bahan kimia beracun dan berbahaya walaupun pada dosis yang rendah sekalipun, akan menyebabkan terjadinya perubahan. Perubahan ini akan dapat menyebabkan perubahan metabolisme dari mikro-organisme endemik dan antropoda yang hidup di lingkungan tanah tersebut. Akibatnya bahkan dapat memusnahkan beberapa spesies primer dari rantai makanan, yang dapat memberi akibat yang besar terhadap predator atau tingkatan lain dari rantai makanan tersebut. Bahkan jika efek kimia pada bentuk kehidupan terbawah tersebut rendah, bagian bawah piramida makanan tercemar bahan kimia asing yang lama-kelamaan akan terkonsentrasi pada makhlukmakhluk penghuni piramida atas.

Pencemaran air adalah keadaan di mana bahan kimia buatan manusia masuk dan merubah lingkungan tanah alami. Penggunaan bahan-bahan kimia berbahaya sudah sering terjadi kasus-kasus kecelakaan, keracunan atau gangguan kesehatan dan lingkungan, baik pada tingkat yang ringan, berat maupun membawa kematian.

Hal ini disebabkan peredaran bahan berbahaya bersifat racun masih di jual bebas (Agenda 21 Indonesia 1996: 8), bahan kimia buatan manusia masuk dan merubah lingkungan tanah alami. Pencemaran ini biasanya terjadi karena: kebocoran limbah cair atau bahan kimia industri masuknya air permukaan tanah tercemar ke dalam

lapisan subpermukaan; zat racun kimia, atau limbah.

Air limbah dari tempat penim-bunan sampah serta limbah industri yang langsung dibuang ke air secara tidak memenuhi syarat (illegal dumping). Ketika suatu zat berbahaya/beracun telah mencemari permukaan tanah, maka zat tersebut akan menguap, dan tersapu air hujan masuk ke dalam tanah dan masuk ke udara.

Pencemaran yang masuk ke dalam tanah kemudian mengendap sebagai zat kimia beracun di air. Zat yang beracun masuk ke dalam tanah dapat berdampak langsung kepada manusia ketika bersentuhan langsung atau dapat mencemari air tanah dan udara di atasnya.

Pencemaran air berdampak langsung terhadap kesehatan manusia, tergantung pada jumlah dan jenis polutan, serta laju masuknya zat beracun tersebut ke dalam tubuh dan kerentaan tubuh manusia yang terkena bahan pencemar tersebut. Kromium dan berbagai macam pestisida, fungisida dan herbisida merupakan bahan karsinogenik untuk semua populasi mahkluk hidup. Timbal sangat berbahaya terutama pada anak-anak, karena dapat menyebabkan kerusakan otak, dan kerusakan ginjal pada manusia.

Lingkungan tercemar akibat peri laku manusia yang kurang arif tampak pada akhir-akhir ini, antara lain: (a) di berbagai kota, seperti ketidak-acuhan terutama lingkungan hidup, ketidakpedulian terhadap sesama yang kurang beruntung, bahwa kesetia-kawanan cenderung meluntur; (b) adanya kesenangan berlebihan pada penggunaan barang-barang simbol teknologi industri canggih dan menginginkan kehidupan yang nyaman tidak ingin menderita, kecenderungan ini dianggap sebagai gaya hidup materialistis yang berlebihan dan tidak memperhatikan kondisi lingkungan, (c) adanya kecenderungan kebiasaan pembuangan sampah seenaknya tanpa memperhatikan dampak, baik kedalam lingkungan air maupun di tempat umum. Hal ini menunjuk gaya hidup atau tingkah laku kebiasaan yang tidak tahu menahunya tentang apa yang boleh dilakukan atau tidak boleh dilakukan.

Hal ini jika dikaitkan dengan sikap dan perilaku kurang memahami suatu permasalahan tentang lingkungan jika dilihat dari sudut pandang pengetahuan atau kemampuan kognitif seseorang tentang pengelolaan lingkungan hidup.

Kondisi mental atau kemampuan kognitif disini mempersoalkan bagaimana cara orang dengan daya untuk memperoleh, mengorganisasi, menyimpan, dan mengingat kembali informasi tentang kondisi lingkungan dalam susunan lingkungan fisik alam.

Kemampuan kognitif mempunyai konsep dasar yang disebut dengan imagibilitas atau kemampuan untuk mendatangkan kesan. 
Imagibilitas mempunyai hubungan yang sangat erat dengan legibilitas, atau kemudahan untuk dapat dipamahami yang dapat diorganisir menjadi satu pola yang koheren serta sikap emosional, untuk berusaha memahami dan mengerti setiap rangkaian keadaan dan peristiwa yang terjadi di sekeliling kita berkaitan dengan empati.

Sesungguhnya, empati baru berarti manakala berlanjut pada tatanan perbuatan. Karena ini serasi digunakan ajaran agama bahwa kesalehan hati harus berlanjut pada kesalehan amal.

Suatu daerah disebut Kampoeng Laweyan Solo merupakan suatu kelurahan dengan luas wilayah 24,83 ha, berpenduduk sekitar 2500 jiwa. Laweyan adalah kampung batik tertua di Indonesia, dengan jumlah UKM batik 22 pengusaha. (http://ukm.prolh.or.id, 2008), adalah salah satu daerah penghasil batik khususnya di Kota Solo di Kecamatan Laweyan merupakan sentra batik kota Solo. Kalurahan Laweyan atau "Kampoeng Batik". Industri batik di Kalurahan Laweyan ini merupakan industri rumah tangga dengan rata-rata produksi $400 \mathrm{~m} /$ hari/perajin dengan air limbah batik cair sekitar $100 \mathrm{~m} 3$ yang langsung dibuang ke Sungai Premulung tanpa diolah terlebih dahulu. Hal ini menyebabkan beban pencemaran yang ditanggung Sungai Premulung semakin tinggi. Limbah cair industri batik yang dibuang tidak diolah, berpotensi mencemari lingkungan karena ditinjau dari parameter warna, kekeruhan, total suspended solids (TSS), dan fenol yang diuji melebihi baku mutu (Ashadi.1996).

Permasalahan yang timbul adalah warna batik pada air buangan. Dalam pewarnaan kain batik tidak semua zat warna yang diberikan akan terserap oleh kain, sehingga akan menimbulkan adanya sisa-sisa zat warna. Menurut Peni limbah warna cair batik di wilayah Laweyan rata-rata mempunyai karakteristik yang melebihi baku mutu air limbah industri tekstil berdasarkan surat keputusan Gubernur Jawa tengah Nomor: 660.01 / 02 / 1997 untuk parameter TSS, phenol, BOD, COD dan logam berat Fe, Mn, Cr (Ashadi: 1996).

Semua tahapan proses produksi pembatikan yang meliputi persiapan, pelekatan lilin, pewarnaan, pelorodan dan pencucian. Identifikasi limbah batik menunjukkan bahwa hampir di semua tahapan proses menimbulkan limbah berupa padat, cair maupun gas yang berbeda komposisi di setiap tahapannya. Pencemaran air oleh industri ini pada umumnya berupa Limbah cair yang banyak mengandung material organik, berbau juga berwarna, bersumber dari proses pencelupan warna pertama.

Menurut Peni (2003:5), limbah cair industri batik di kelurahan Laweyan memiliki karakteristik pewarna pekat dan berbau serta BOD, COD, TSS dan phenol melebihi ambang batas yang ditetapkan oleh Gubernur Jawa Tengah No. 10 tahun 2004. Parameter TSS $220 \mathrm{mg} / \mathrm{L}$, COD $120 \mathrm{mg} / \mathrm{L}$, BOD 51,03 mg/L, minyak dan lemak 11 mg/L (Okid Parama Astirin, 2000: 13:19)

Meskipun kadar fenol sangat rendah hal ini dapat mengganggu aktivitas mikrobia, seperti bahwa pada konsentrasi yang sangat rendah fenol dapat bersifat toksik pada kehidupan biologi tingkat rendah. Meskipun limbah batik telah diolah (dalam kolam pengendapan) secara digesti anaerob, ternyata masih mengandung senyawa amonia yang dapat mengganggu lingkungan. Kadar amonia dalam limbah maupun efluen dapat diturunkan oleh aktifitas mikrobia yang bersifat aerob. Mikrobia aerob ini diperoleh dari cairan limbah batik yang sangat berperan dalam melakukan proses oksidasi. Proses oksidasi sempurna oleh mikrobia terhadap bahan organik dalam limbah akan menghasilkan $\mathrm{CO}_{2}, \mathrm{H}_{2} \mathrm{O}$, ammonia, hidrogen sulfida dan energi. Proses yang terjadi dalam lumpur aktif adanya peruraian amonia untuk meningkatkan nilai DO yang rendah. Selanjutnya amonia secara hayati dioksidasi menjadi nitrit, kemudian nitrit dioksidasi menjadi nitrat. Nitrat merupakan hasil oksidasi terakhir.

Hal yang perlu diperhatikan masalah limbah cair yang dihasilkan oleh industri batik pada umumnya disebabkan oleh proses basah, yaitu pencucian batik yang telah diolah dengan air panas untuk menghilangkan malam ataupun untuk mencuci bekas soga, indigo (pewarna batik). Proses produksi batik ini banyak menghasilkan limbah cair berupa warna pekat, sehingga sangat berbahaya bagi kesehatan apabila di buang ke badan air. Pembuatan batik yang paling banyak menimbulkan pencemaran adalah proses basah, yaitu pekerjaan batik dalam larutan zat kimia dengan air sebagai mediumnya dan sebagai bahan pembantu yang terdiri dari kanji, minyak, lilin, soda $(\mathrm{NaOH})$, deterjen dan lain-lain.

Berdasarkan survai pendahuluan bak-bak pengendap air limbahnya sebelum air limbah tersebut dibuang langsung ke badan air. Namun demikian pada bak-bak pengendap air limbah tersebut belum cukup mengatasi pencemaran yang telah ditimbulkan.

Menurut Sulastoro Ahli lingkungan dari Universitas Sebelas Maret Surakarta, limbah industri batik pada umumnya mengandung zat beracun, seperti Natrium (Na), Cadmium (Cd), dan Chrom (Cr). Berdasarkan penelitian Retno pada akhir tahun 2006, air Sungai Bengawan Solo di sekitar Sukoharjo hingga Sragen sudah tercemar logam berat yang melewati ambang batas, seperti Chrom dan Cadmium. Di sejumlah tempat di sisi Bengawan Solo sejak Surakarta hingga Kabupaten Karanganyar menunjukkan banyak ikan sapu-sapu (suckermouth) yang mati. Ikan jenis itu biasanya bertahan pada air keruh atau kotor. Sebaliknya, ikan nila dan bader yang banyak ditangkapi masyarakat di bagian hulu tidak lagi ditemukan, menunjukkan kualitas air Sungai Bengawan Solo sekitar Sukoharjo, Surakarta, dan Sragen sudah tercemar berat. (http://www.indowater.org/?) Hal lain terbukti dengan adanya hasil pemeriksaan sampel uji air limbah industri batik di sentra batik Laweyan Surakarta terhadap parameter logam $\mathrm{Pb}^{2+}, \mathrm{Cd}^{2+}$, angka BOD dan COD melebihi baku mutu air limbah industri berdasarkan SK Gubernur Jateng. (Peni Pujiastuti, Vol.1 No.2)

Pada industri batik dalam proses produksinya menggunakan beberapa bahan pewarna, zat warna yang biasa digunakan umumnya zat warna sintetik, karena harganya murah dan memberikan hasil yang lebih baik memuaskan, tetapi limbah yang dihasilkan masih berwarna dan sulit terdegradasi oleh alam, sehingga dapat mengganggu estetika maupun penetrasi sinar matahari ke dalam badan air yang pada gilirannya akan menurunkan kualitas lingkungan.

Air limbah yang baru dibuang biasanya berwarna abu-abu, apabila senyawa-senyawa organik yang ada mulai pecah oleh bakteri, warna menjadi hitam pekat dan bau tidak sedap menyengat, sehingga oksigen terlarut dalam limbah direduksi sampai menjadi nol dan warnanya berubah. Pada kondisi ini dikatakan bahwa air limbah sudah membusuk. Dalam menetapkan warna tersebut dapat pula diduga adanya pewarna tertentu yang mengandung logamlogam berat.

Pelaksanaan sistem industri batik mengenal tindakan produksi bersih yang direkomendasikan untuk dijalankan adalah pencegahan pencemaran. Resiko lingkungan yang harus diperhatikan dan merupakan urutan prioritas penanganan limbah cair batik, bahwa urutan limbah yang perlu ditangani sesuai dengan prioritasnya adalah sisa pewamaan, sisa pelorodan, sisa peloyoran dan sisa pencucian. Kondisi air tanah atau air permukaan di kawasan sekitar kali (sungai) Jenes diduga tercemar limbah industri.

Program pengembangan Kampung Batik di Laweyan, Solo, belum dibarengi dengan perwujudkan sistem sanitasi yang baik. Itu terkait fasilitas Instalasi Pengolahan Air Limbah (IPAL) untuk limbah buangan cair yang masih minim. Alhasil Limbah cair dari proses pembatikan yang dibuang ke sungai, mencemari lingkungan sekitar. Tidak aneh kalau sungai yang melintas dikawasan Kampung Batik Laweyan tercemar.

Tanggapan efektif terhadap ancaman lingkungan oleh limbah cair batik seharusnya memberikan keterpamahaman manusia tentang hubungan manusia dengan sistem alami bumi. Perubahan dan pembaharuan sikap dan nilai budaya terhadap lingkungan dan alam harus sudah dilakukan umat manusia.

Makin majunya teknologi industri batik makin besar pula masalah yang berdampak buruk terhadap kehidupan mahkluk hidup baik manusia, hewan dan tumbuhan, karena pembuangan limbah produksi pabrik berupa bahan pewarna sebagai pemicu rusaknya lingkungan. 
Bahan kimia yang mengandung Bahan Beracun Berbahaya(B3) sebagai suatu zat pencemar biosfer, serta merupakan zat yang asing terhadap kehidupan, yang biasanya dibuat secara sintetik. Bahan kimia ini sebenarnya sangat besar manfaat bagi manusia.

Bahan kimia ini dalam situasi yang mencakup pemakaian atau suatu pengaruh terhadap kehidupan, sehingga zat tersebut terserap dan terbioakumulasi atau akumulasi suatu bahan kimia yang bersifat B3 masuk ke dalam tubuh mahluk hidup dengan suatu tingkat kepekatan yang cukup tinggi (Conell, Dess W, 1995:2)

Pencemaran air oleh industri batik ini pada umumnya berupa Limbah cair yang banyak mengandung material organik, berbau juga berwarna, bersumber dari proses pencelupan warna pertama (Okid Parama Astirin, 2000:13-19).

Abimanyu menjelaskan, sejumlah industri rumah tangga batik seperti di Laweyan, Sondakan, dan Premulung, hingga kini belum memiliki pengolahan limbah sendiri. Akibatnya, mereka seenaknya membuang limbah cair obat batik(http://www.depkominfo.go.id/2009/07/31). Berakibat menurunnya kualitas air Bengawan Solo ke arah hilir terus memburuk, akibatnya pencemaran limbah industri, rumah tangga, maupun usaha peternakan. Air yang mengalir dari sejumlah anak sungai ke Bengawan Solo tampak berwarna coklat, hitam, dan ungu, serta menebarkan aroma tidak sedap. Limbah terlihat di sekitar Dusun Bacem, Desa Langenharjo, Kecamatan Serengan, Surakarta, hingga ke hilir. Limbah bahan pewarna tekstil mulai mencemari sungai di sekitar Kali Pepe yang bermuara lebih ke hilir Bengawan Solo, tepatnya di Kampung Sewu, Kelurahan Sewu, Kecamatan Jebres, Surakarta, mengalirkan air berwarna ungu. yang airnya tampak berwarna coklat kehitaman dan bermuara ke Bengawan Solo adalah Kali Premulung (dikenal juga sebagai Kali Wingko). Limbah itu berasal dari industri pengecatan batik di Laweyan. Selain mencemari sungai, limbah itu juga mencemari udara karena menebarkan bau tak sedap.

Penelitian tim dari Pusat Penelitian Lingkungan Hidup (PPLH) UNS menyebutkan bahwa air di beberapa sumur penduduk yang dijadikan sampel menunjukkan adanya sejumlah kandungan yang melebihi baku mutu seperti digariskan dalam Peraturan Pemerintah Nomor 82 Tahun 2001 tentang Kualitas Air.

Berdasarkan hasil survei pihak pengelola Forum Pengembangan Kampoeng Batik (FPKB) Laweyan, ternyata kegiatan IPAL sampai saat ini baru diikuti 11 industri batik dengan kapasitas produksi menengah ke atas. Sementara di Kampoeng Laweyan dan sekitarnya masih terdapat puluhan industri kecil batik yang belum mendapat pengetahuan tentang bahaya pewarna sintetis batik yang dapat cemari lingkungan.

Hal ini menjadikan sejumlah warga di wilayah RT 04/RW I Laweyan mengeluhkan adanya bau tak sedap yang ditimbulkan oleh IPAL Laweyan. Bau tersebut semakin tajam dan menyengat, terutama saat musim kemarau. Bau limbah tersebut, diakui sangat mengganggu pernafasan warga sekitar. Dari hasil pemantauan lapangan dan hasil uji laboratorium yang dilakukan, IPAL ini masih berbau, berwarna dan mempunyai parameter yang melebihi baku mutu lingkungan, antara lain: TSS $32 \mathrm{mgr} / \mathrm{l}$ dan COD 16,56 mgr/l (Puji Astuti, P. \& Supadmi, R, 2007:15).

Limbah industri batik pada umumnya mengandung zat beracun, seperti Natrium (Na), Cadmium (Cd), dan Chrom (Cr). Air Sungai Bengawan Solo sudah tercemar logam berat yang melewati ambang batas,

seperti Chrom,Cadmium(http://www.indowater.org/?)

Pewarna kimia berbahaya seperti Naptol yang lazim digunakan dalam industri batik, merupakan bahan kimia yang termasuk dalam kategori B3 (bahan beracun berbahaya) ini dapat pemicu terbentuk kanker pada kulit. Selain itu, limbah pewarna yang dibuang sembarangan, juga bisa mencemari lingkungan sungai, sehingga ekosistem sungai tercemar. Akibatnya, ikan-ikan mati dan air sungai tidak dapat dimanfaatkan lagi.

Lebih dari itu, air sungai yang telah tercemar pewarna kain batik meresap ke sumur dan mencemari sumur. Padahal air itulah yang digunakan untuk keperluan hidup sehari-hari. Keadaan semacam ini telah dialami oleh banyak warga, terutama di sentra industri batik. Masyarakat di sekitar Bengawan Solo telah lama mengeluhkan akibat pencemaran limbah kain batik ini. Utama Sungai Bengawan Solo, mengalirkan limbah batik dari pabrik-pabrik industri batik besar maupun kecil yang membuang limbahnya ke sungai.

Aktifitas industri batik disamping memberikan pengaruh positif juga memberikan dampak negatif yang menghasilkan limbah cair dengan kandungan warna, zat padat yang tersuspensi, BOD, COD, phenol, Crom, minyak lemak dan $\mathrm{pH}$ yang perlu pengolahan sebelum dibuang ke badan air (Pudji Setyaningsih, 2005).

Mulai tahun 1988, air sungai Kali Bengawan Solo sudah sangat kotor. Sejak tahun itu, perubahan warna sungai akibat pencemaran limbah cair dari pabrik yang juga mengeluarkan bau seperti bangkai yang menyengat diikuti oleh matinya ikan-ikan, banyak ternak yang mati, dan juga kesehatan yang terganggu seperti penyakit kulit.

Beberapa pabrik berskala besar membangun IPAL, untuk mengolah limbah cair industri batik. Namun, jumlah itu tak sepadan dengan limbah yang dihasilkan setiap hari. Pengusaha yang abaikan terhadap pengolahan limbah jauh lebih banyak.

Namun, mereka belum juga menganggarkan pengelolaan limbah ke dalam pos biaya produksi, sehingga masih enggan untuk mengolah limbah sebelum dialirkan ke sungai. Masih banyak pengusaha yang beranggapan, pengelolaan dan pengolahan limbah hanya menjadi tanggung jawab pemerintah. Hal ini karena para pengusaha tidak atau kurang memiliki pengetahuan dan tidak peduli tentang bahaya racun dari pewarna batik sintetis yang mereka buang ke dalam sungai (lingkungan air).

Pembangunan Unit Pengelolaan Limbah Terpadu yang diprakarsai pemerintah, seperti yang telah ada di Laweyan, mungkin menjadi alternatif bagi perajin kecil yang tak mampu mengelola sendiri limbahnya karena besarnya investasi. Namun, jumlah unit pengolahan limbah terpadu jauh dari memadai, sehingga perlu ditambah jumlah maupun kapasitasnya.

Menurut data, kapasitas unit pengolah limbah di kampoeng batik Laweyan ini baru mencapai 400 meter kubik perhari, sementara limbah yang dihasilkan mencapai 700 meter kubik perhari. Belum lagi limbah dari sentra-sentra industri batik lainnya. Parameter fisika diperoleh rata-rata TSS pada sungai Jenes adalah berkisar 62, COD 88,6, BOD 228 dan PH 6,8.

Proses pewarnaan batik, biasanya menggunakan jenis warna napthol dan indigosol. Napthol mempunyai ikatan rangkap dua nitrogen $(-\mathrm{N}=\mathrm{N}-)$. Penyisihan warna dari kromofor azo dapat dicapai dengan reduksi dari ikatan azo $(-\mathrm{N}=\mathrm{N}-)$ (Michelsen, 1993).

Pada kondisi anaerob, ikatan azo direduksi dan dipecah menjadi aromatik amine, dimana aromatik amine tersebut sulit didegradasi secara anaerob, namun dapat didegradasi secara aerob. Beberapa aromatik amine dilaporkan bersifat toksik dan karsinogenik. Maka dari itu degradasi secara anaerob tidak bisa merupakan pengolahan terakhir dari zat warna azo. Pengolahan lengkap yaitu rangkaian pengolahan anaerob dan aerob adalah pengolahan yang tepat untuk mendegradasi zat warna azo (Pudji Setyaningsih, 2006).

Efek negatif pewarna kimiawi dalam proses pewarnaan oleh perajin batik adalah risiko terkena kanker kulit. Ini terjadi karena saat proses pewarnaan, umumnya para perajin tidak menggunakan sarung tangan sebagai pengaman, kalaupun memakai pewarna sintetis, tidak benar-benar melindungi dengan maksimal. Akibatnya, kulit tangan terus-menerus bersinggungan dengan pewarna kimia berbahaya seperti Naptol yang lazim digunakan dalam industri batik. Bahan kimia yang termasuk dalam kategori B3 (bahan beracun berbahaya) ini dapat memacu kanker kulit.

Selain itu, limbah pewarna yang dibuang sembarangan di lingkungan air. Ekosistem sungai rusak. Akibatnya, ikan-ikan mati dan air sungai tidak dapat dimanfaatkan lagi. Lebih dari itu, air sungai yang telah tercemar meresap ke sumur dan mencemari sumur. Padahal air itulah yang digunakan untuk keperluan hidup sehari-hari. 
Masalah yang mendasar keadaan semacam ini telah dialami oleh banyak warga dekat sungai, terutama di sentra industri batik. Masyarakat di sekitar sungai Jenes misalnya, yang telah lama mengeluhkan akibat pencemaran limbah batik ini. Kali Jenes, sungai yang membelah bagian timur dari selatan ke utara ini, mengalirkan limbah batik dari pabrik-pabrik industri batik besar "Kampoeng Batik Laweyan"

Namun beberapa pabrik berskala besar memang telah membangun IPAL untuk mengolah limbah cair industri batik. Namun, jumlah itu tak sepadan dengan limbah yang dihasilkan setiap hari. Pengusaha yang lalai terhadap pengolahan limbah jauh lebih banyak.

Permasalahan-permasalahan IPAL yang sangat memprihatinkan karena mereka belum menganggarkan pengelolaan limbah ke dalam pos biaya produksi, sehingga masih enggan untuk mengolah limbah sebelum dialirkan ke sungai. Masih banyak pengusaha yang beranggapan, pengelolaan dan pengolahan limbah hanya menjadi tanggung jawab pemerintah.

Pembangunan Unit Pengelolaan Limbah Terpadu yang diprakarsai pemerintah, seperti yang telah ada di kalurahan laweyan, mungkin menjadi alternatif bagi perajin kecil yang tak mampu mengelola sendiri limbahnya karena besarnya investasi. Namun, jumlah unit pengolahan limbah terpadu jauh dari memadai, sehingga perlu ditambah jumlah maupun kapasitasnya. Meski nilai investasi pembangunan unit pengolahan limbah terpadu, menelan anggaran Rp 1,7 miliar namun upaya ini tetap harus dilakukan. Jika tidak, kelangsungan hidup warga akan terancam karena kualitas air tanah dan sungai menurun akibat pencemaran.

Hal yang sangat perlu diperhatikan pada penggunaan bahan pewarna kimiawi dalam industri batik tulis mengandung resiko bagi masyarakat dan lingkungannya. Padahal penggunaannya saat ini sudah meluas di berbagai daerah, termasuk oleh para perajin batik tulis. Sudah terlanjur digunakan secara luas, penggunaan pewarna kimiawi tak dapat begitu saja dialihkan kepada pewarna alami. Perlu ada sosialisasi dan penyuluhan kepada para perajin kecil batik

Dengan merebaknya pola dan gaya hidup materialistis, konsumtif, dan hedonistis, yang melanda masyarakat kita belakangan ini, diakui atau tidak, telah membikin perspektif kita terhadap nilai-nilai kemanusiaan menyempit. Kesibukan berurusan dengan gebyar duniawi, disadari atau tidak, telah membuat kita abai terhadap persoalan esensial yang menyangkut interaksi sosial terhadap sesama. Pada dasarnya sifat manusia suka menolong merupakan bagian dari "sifat manusia” yang ditentukan secara genetik, sangat kontroversial. Setiap tindakan yang dilakukan orang dengan tidak mempertimbangkan untung ruginya.

Perilaku menolong untuk ikut merasakan penderitaan orang lain sebagai penderitaan sendiri merupakan rasa empati.

Kecenderungan rasa empatik hanya dapat dikurangi dengan membantu orang berada dalam kesulitan, dan rasa empatik merupakan sumber altruistik (bukan kepentingan diri) sebagai perilaku membantu orang lain yang diasumsikan terhadap lingkungan yang mengalami penderitaan yang disebabkan oleh pencemaran (David O Sears, 1991:69)

Berbagai hasil budaya yang dipunyai masyarakat cukup tinggi, dan nilai tersebut seharusnya dapat dijadikan "bahan baku" untuk membangun kesadaran terhadap pentingnya fungsi lingkungan sebagai tempat hidup. Saat ini baik nilai budaya maupun lingkungan mengalami perusakkan cukup intensif. Jika hal ini dibiarkan berkelanjutan, maka abad 21 berakhir kondisi lingkungan semakin parah.

Dengan membangun pengetahuan dan nilai moral (budaya) manusia akan dapat menghormati batas kemampuan hukum alam yang harus dipatuhi. Ada 3 (tiga) penyebab terjadinya kerusakan lingkungan pada skala masif, yaitu: pertama, tidak terkendalinya nilai keserakahan yang mengiringi pembangunan sosial dan ekonomi yang berwatak kapitalistik. Kedua, tidak mampunyai kalangan ilmuwan berpengetahuan untuk meyakinkan penyelenggara negara untuk membangun masyarakat manusia yang cerdas (smart civil Society) yang menempatkan aspek pengelolaan lingkungan hidup secara kolektif pada posisi strategis. Ketiga besarnya kelompok lapisan masyarakat miskin, masih kurang pengetahuan tentang lingkungan, yang kehidupannya sangat tergantung pada lingkungan alam (Tri Pranadji: 2005: 313-315).

Pada dasarnya setiap orang cenderung menirukan perilaku dan gaya hidup yang disekiranya memberikan manfaat, kesenangan dan perasaan bangga pada dirinya, atau cara baru untuk memenuhi kebutuhan hidupnya. Setelah beberapa lama mereka cenderung merasakan sesuatu ketidaktentraman dan ketidakpuasan, tetapi pengetahuan mereka bertambah, imajinasi terpancing, keinginan baru muncul dan kecenderungan mengkonsumsi meningkat (Paraswati D.M. 1992:67).

Mengubah kebiasaan dan tingginya gaya hidup yang telah berlangsung dan berkembang sedikitnya selama satu abad terahkir ini ternyata tidaklah mudah, industri-industri yang telah tumbuh, pola konsumsi diberbagai masyarakat. Semua merupakan kubukubu yang tidak mudah dipecahkan dan diganti yang baru dan tidak merusak baik sumber-sumber hidup maupun lingkungan hidup pada semua kehidupan di dunia (Al Gore, 1994: xvi)

Pembaharuan gaya hidup dan nilai sosial budaya serta perubahan perilaku, perusakan alam karena keserakahan oleh manusia untuk mengekploitasi alam berdampak kepada perubahan lingkungan alam berkelanjutan. Dari hasil pengamatan di lapangan sudah begitu jelas pencemaran limbah industri batik sangat serius, terutama daerah dekat pusat industri terutama yang berakibat langsung pada masyarakat dekat pembuangan limbah, hal ini berdampak pada perusakkan nilai-nilai budaya yang mengarah pada kerukunan yang tidak berjalan sebagaimana mestinya, sehingga berkurangnya tenggang rasa.

Nilai budaya yang hidup di masyarakat merupakan nilai budaya yang digunakan untuk memprediksi atau menilai masyarakat tentang pendapat, apresiasi, sikap dan kepecayaan terhadap hasil produksi batik, dalam penerapan berbagai bidang kehidupannya dan kegiatan tertentu yang dijalankan masyarakat termasuk perhatian dalam pengelolaan lingkungan.

Dari beberapa kejadian dapat disimpulkan bahwa masyarakat cenderung egosentris, kurang peka terhadap lingkungannya, gaya hidup konsumtif dan sering melakukan jalan pintas demi kepuasan pribadi(Iman Santosa Sukardi, 1993: 19-20)

Permasalahan tersebut mendorong peneliti untuk melakukan penelitian tentang faktor-faktor yang dapat meningkatkan empati lingkungan atas banyaknya pewarna batik sintetis yang berdampak terhadap keselamatan lingkungan berakibat terhadap kesehatan lingkungan masyarakat, yaitu berdasarkan kemampuan kognitif, nilai budaya dan gaya hidup diharapkan dengan melakukan penelitian ini, mampu memberikan sumbangan pemikiran dalam memperbaiki dan meningkatkan kesadaran para pengrajin batik industri kecil maupun besar.

\section{B. Identifikasi Masalah}

Berdasarkan uraian tersebut yang telah diungkapkan, secara garis besar terdapat beberapa faktor penting yang terkait mempengaruhi pemahaman masyarakat dalam empati lingkungan yaitu berupa faktor internal yang terdiri dari: berfikir, mengenal kesadaran, kecerdasan, norma, sikap, apresiasi, tingkah laku , aktivitas, opini, interest, etika. Selanjutnya faktor eksternal antara lain kondisi lingkungan kota, saluran air sungai, kondisi industri batik.

Untuk jelas permasalahan yang berhubungan dengan pemahaman masyarakat terhadap kondisi lingkungan hidup yang tercemar oleh limbah pewarna batiktergambar dalam pertanyaan di bawah ini:

1. Mengapa rasa empati ling-kungan masyarakat rendah?

2. Faktor apa saja yang ber-hubungan dengan rasa empati lingkungan rendah?

3. Apakah kemampuan kognitif berhubungan dengan rasa empati lingkungan? 
4. Apakah nilai budaya ber-hubungan dengan rasa empati lingkungan?

5. Apakah gaya hidup ber-hubungan dengan rasa empati lingkungan?

6. Jika kemampuan kognitif masyarakat tinggi apakah rasa empati lingkungan juga tinggi?

7. Jika nilai budaya masyarakat tinggi apakah rasa empati lingkungan juga tinggi?

8. Jika gaya hidup masyarakat tinggi apakah rasa empati lingkungan juga tinggi?

9. Jika kemampuan kognitif, nilai budaya dan gaya hidup masyarakat tinggi, apakah rasa empati lingkungan juga tinggi?

10. Apakah kepedulian pemerintah dapat mengatasi pencemaran lingkungan?

11. Apakah kepedulian pemerintah daerah dapat mengatasi pencemaran lingkungan?

12. Apakah dengan penyuluhan dapat meminimalisasi pencemaran?

13. Apakah lokasi pembuangan limbah pewarna batik dapat disiapkan oleh pemerintah daerah?

\section{Pembatasan Masalah}

Menyadari begitu kompleksnya permasalahan yang terkait dengan fenomena limbah cair dari produksi batik yang berdampak pada pencemaran lingkungan air yang disebabkan oleh begitu banyaknya kandungan racun yang berakibat matinya organisme hidup di air dan perubahan kondisi lingkungan masyarakat yang bertempat tinggal di sekitar sungai aliran limbah, sehingga air yang berwarna tersebut mencemari sumur-sumur penduduk yang dipergunakan sebagai pemenuhan kebutuhan hidup sehari-hari, hali ini akan berdampak terhadap kesehatan masyarakat. Dalam hal bagaimana empati masyarakat memandang kondisi seperti itu memiliki hubungan rasa empati untuk membantu memecahkan masalah yang sedang berlangsung dengan kemampuan kognitifnya, merubah gaya hidup dan mengembangkan nilai-nilai budaya.

Kemampuan kognitif yang dikaji dalam penelitian meliputi cara berpikir, menggunakan kecerdasannya, dengan mengenal ciriciri limbah cair yang terdapat di sungai pembuangan dan kesadaran akan gejala yang akan terjadi akibat dampak pencemar.

Gaya hidup yang dikaji yang meliputi aktivitas penggunaan kain batik dalam kehidupan sehari-hari, interest atau ketertarikan pada seni batik dan opini merupakan pendapat perkembangan seni batik.

Sedang nilai budaya ditinjau dari pendapat mengenai dampak limbah cair yang dihasilkan oleh para pengrajin batik tanpa mengindahkan keselamatan masyarakat mereka hanya berfokus pada keuntungan diri pribadi, sikap positif dan negatif cara konsisten terhadap situasi yang terjadi di lapangan, apresiasi atau penghargaan yang sangat tinggi terhadap karya seni yang dikembangkan secara secara kreatif melalui kriya batik dan percaya akan batik merupakan seni tradisional, mengandung mistik dan kesakralan yang cukup tinggi.

\section{Perumusan Masalah}

Berdasarkan identifikasi masalah dan pembatasan masalah tersebut di atas, maka permasalahan yang diteliti dalam penelitian ini dirumuskan sebagai berikut:

1. Apakah terdapat hubungan kemampuan kognitif dengan empati lingkungan?

2. Apakah terdapat hubungan nilai budaya dengan empati lingkungan?

3. Apakah terdapat hubungan gaya hidup dengan empati lingkungan?

4. Apakah terdapat hubungan antara kemampuan kognitif, nilai budaya dan gaya hidup secara bersama-sama dengan empati lingkungan?

\section{E. Manfaat Penelitian}

\section{Manfaat Teoretik}

b. Meningkatkan pengetahuan masyarakat tentang limbah berwarna dari batik secara khusus dan secara umum dan tentang B3.

c. Mewaspadai akan bahaya yang ditimbulkan oleh limbah batik secara khusus dan yang ditimbulkan limbah B3 secara umum.

d. Mensosialisasikan kepada masyarakat kaitannya dengan masalah limbah batik secara khusus dan secara umum tentang limbah B3.

\section{Manfaat Praktik}

a. Mewaspadai kerusakan ling-kungan yang ditimbulkan oleh pencemaran limbah batik / B3

b. Mengubah gaya hidup masyarakat yang terkena limbah batik menjadi masyarakat yang berbudaya sehat lingkungan.

c. Menyediakan tempat praktek daur ulang teknologi tepat guna agar limbah batik serta limbah B3 tidak membahayakan lagi bagi kelangsung kehidupan mahkluk di bumi

\section{KERANGKA TEORETIK}

\section{Empati Lingkungan}

\section{a. Empati}

Ditinjau dari asal kata empati dalam bahasa Jerman ” Einfülung” yang memiliki arti "perasaan yang mendalam” juga sering diartikan sebagai "dengan perasaan". M.F. Basch dalam Alison mencatat dalam bahasa Junani bahwa empati ditu-runkan dari perfik "em" yang berarti "pada" atau "dalam“. Empati merupakan kemampuan memahami kea-daan orang lain yang dilandasi "perasaan yang mendalam” dan pe-ngalaman yang sebenarnya pada keadaan itu. Basch mengatakan dalam synonim bahasa Jerman "sich hineinversetzen" (meletakkan diri sendiri pada diri orang lain) dan "fremdwarhrnehmung" (tahu perihal orang lain) pernyataan langsung me-liputi perihal orang lain.

Menurut Lauren Wispe dalam hal empati adalah keadaan untuk mengerti, dan merupakan suatu penyatuan diri sendiri pada diri orang lain (Alison Bernes dan Paul Thagard 1997:2-3).

Empati dalam infoplease internet dijelaskan bahwa : (1) indikasi suatu kecerdasan atau seolah mengalami sendiri dengan perasaan, berpikir tentang perilaku orang lain; (2) penderitaan orang lain sebagai gambaran pantulan diri sendiri.

Menurut Daniel Goleman, empati merupakan peniruan secara fisik atas beban orang lain, yang kemudian menimbulkan perasaan yang serupa pada diri seseorang dan merupakan fakta biologis berupa ekspresi wajah gerak-gerik tertentu, sehingga orang yang empatik akan memberikan perhatian dengan sungguh-sungguh atas kemalangan yang disebabkan oleh kesalahan dirinya sendiri (http:www. infoplease. Com/ipd/ A0424447.html).

The Encyclopedia Britanica (edisi 1999) oleh Carl Rogers melanjutkan te-laahnya tentang empati yaitu ke-mampuan membayangkan dirinya akan orang lain dan mengerti perasaannya, hasrat, gagasan dan tindakannya. Hal ini menunjuk beberapa elemen empati adalah: (a) membayangkan disini tergantung kemampuan subjek untuk membuat suatu gambaran yang jelas tentang penderitaan objek; (b) adanya keterbukaan diri sendiri dengan kepedulian, kesadaran diri; (c) adanya kesadaran untuk mengenal dunia luar dirinya; (d) adanya keterbukaan perasaan, hasrat, gagasan dan mewujudkan tindakan atau hasil antara empator dan objek empati; (e) adanya kerangka rujukan yang tepat yakni adanya kerangka rujukan moral. (Western, 1996: 480).

Pada berbagai hubungan antara subjek dan objek empati terjadi adalah: (a) hubungan tertutup antar subjek dan objek terjadi secara eksplisit persetujuan komunikasi antar ke duanya; (b) meliputi sesuatu di luar (disebut "objek" antara); (c) diidentifikasi sebagai kecerdasan seseorang seolah mengalami sendiri perasaan dan pikiran adanya tingkah laku orang lain; (d) gambaran yang jelas tentang diri dari objek (Barnes and Thagard, 1997 : 2). 
interaksi antar subjek dan objek ini merupakan suatu bentuk kehidupan tidak hanya dengan emosi empati, tetapi juga aktivitas fisik, dimana menunjuk pada situasi lingkungan tercemar oleh B3 di perairan sungai oleh limbah batik, sudah melebihi ambang batas karena perilaku para industri batik, sehingga hal ini sangat mengganggu bagi kelangsungan hidup mahkluk di air dan masyarakat sekitar area pembuangan limbah.

Proses empati melibatkan empat unsur penting, yaitu drive, cue, respond dan reward. Drive merupakan ransangan yang kuat yang memaksa seseorang untuk melakukan tindakan, Cue atau isyarat merupakan sesuatu yang dapat membedakan antara satu dengan yang lain serta dapat mengartikan penderitaan yang sedang terjadi. Respond merupakan tangga-pan perilaku yang sebenarnya akibat isyarat tadi. Selanjutnya reward atau imbalan merupakan peristiwa sebagai akibat dari respon tertentu. Kemampuan empatik yang harus dilakukan dengan mengembangkan kemampuan membedakan isyarat tersebut.

\section{b. Lingkungan}

Menurut Lynton Keith Caldwell lingkungan adalah keseluruhan yang mengitari, termasuk yang dikitari yaitu manusia(Lynton Keith Caldwell,1970: 5) merupakan kombinasi antara kondisi fisik yang mencakup keadaan sumber daya alam seperti tanah, air, energi surya, mineral, serta flora dan fauna yang tumbuh di atas tanah maupun di dalam lautan, dengan kelembagaan yang meliputi ciptaan manusia seperti keputusan bagaimana menggunakan lingkungan fisik tersebut. Lingkungan terdiri dari komponen abiotik dan biotik. Komponen abiotik adalah segala yang tidak bernyawa seperti tanah, udara, air, iklim, kelembaban, cahaya, bunyi. Sedangkan komponen biotik adalah segala sesuatu yang bernyawa seperti tumbuhan, hewan, manusia dan mikro-organisme (virus dan bakteri) (http://id.wikipedia.org/wiki/Daftar_istilah_lingkungan_hidup).

Menurut St. Munajat Danusaputra lingkungan adalah semua benda dan kondisi termasuk di dalamnya manusia dan tingkah perbuatannya, yang terdapat dalam ruang dimana manusia berada dan mempengaruhi kelang-sungan lingkungan hidup serta kesejahteraan manusia dan jasad hidup lainnya.

Menurut Otto Soemarwoto, Lingkungan adalah jumlah semua benda dan kondisi yang ada dalam ruangan yang kita tempati yang mempengaruhi kehidupan kita. Secara teoritis ruang itu tidak terbatas jumlahnya, oleh karenanya misalnya matahari dan bintang termasuk di dalamnya.

Ruang merupakan sesuatu di mana berbagai komponen lingkungan hidup menempati dan melakukan proses. Dengan demikian di manapun terdapat komponen lingkungan hidup, maka di situ terdapat ruang dan komponen lingkungan merupakan suatu kesatuan(Valentinus Darsono, 1994:12-15)

Daya atau energi adalah sesuatu yang memberi kemampuan untuk melakukan kerja. Manusia, binatang dapat melakukan sesuatu karena di dalam tubuhnya terdapat energi.

Keadaan disebut juga dengan kondisi atau situasi, ada yang membantu berlangsungnya situasi di dalam sistem, ada yang merangsang makhluk hidup melakukan sesuatu dan ada pula situasi atau kondisi yang menghambat interaksi di dalam sistem.

Menurut Edmunds dan Letey proses interaksi antara organisme dengan lingkungannya di dalam suatu ekosistem terdiri empat aliran: (1) siklus pendukung; (2) penyebaran atau distribusi species; (3) dampak kegiatan manusia terhadap lingkungan dan (4) pelestarian lingkungan. Diantara keempat aliran ekosistem itu, yang pertamalah yang terpenting, kemudian yang ke tiga dan keempat. (Edmunds, Stharl dan John Letey, 1973: 121)

Lingkungan sudah ada sejak sebelum manusia berada di bumi, hal ini menunjukkan bahwa keberadaan manusia di atas bumi sangat di pengaruhi oleh atau tergantung pada apa yang terdapat di bumi, maka dari itu tergantung pada apa yang terdapat di bumi, maka dari itu manusia tidak dapat hidup sendirian tanpa adanya mahkluk hidup di sekitarnya maupun komponen yang lain sekaligus sebagai sumber kehidupannya
Manusia secara ekologis adalah bagian dari lingkungan hidup. Kelangsungan hidup manusia tergantung dari keutuhan lingkungan-nya. Manusia terbentuk karena lingkungannya, oleh karena itu lingkungan hidup tidak semata-mata hanya dipandang sebagai sumber daya yang harus di eksploitasi melainkan terutama sebagai tempat hidup yang mensyaratkan adanya keserasian antara manusia dan lingkungan hidupnya.

Pengaruh sikap "frontier” manusia terhadap lingkungan akan merubah lingkungan seperti yang apa dikehendaki oleh manusia tidak mengingat anak cucu masih mem-butuhkan sumber alam untuk ke-hidupan selanjutnya. (Darsono,1994 : 14).

Moh. Suryani, berpendapat bahwa lingkungan hidup merupakan sistem kehidupan, dimana terdapat campur tangan manusia terhadap tatanan ekosistem. Sedangkan lingkungan hidup adalah suatu sistem yang merupakan kesatuan ruang dengan semua benda, sumber daya keadaan dan mahkluk hidup termasuk manusia dan perilakunya yang menentukan perikehidupan serta kesejahteraan manusia dan mahkluk lainnya (Moch. Suryani,1987: 3-4).

B3 sesuai dengan Surat Keputusan Menteri Perindustrian No. 148/M/SK/4/1985 di mana yang suatu bahan dinyatakan sebagai B3 adalah yang memenuhi kriteria: a) bersifat racun; b) mudah meledak; c) mudah terbakar dan menyala; d) bersifat oksidator dan reduktor; e) gas bertekanan tinggi; f) mudah korosi/ iritasi; g) bahan bersifat radioaktif; h) B3 yang ditetapkan oleh Menteri. (P.L Countier,1993: 29).

Karakteristik B3 adalah sebagai berikut: mudah meledak atau melalui reaksi kimia dan fisika dapat menghasilkan gas dengan suhu dan tekanan tinggi yang dengan cepat dapat merusak lingkungan sekitar; (b) mudah terbakar yakni bahan yang berupa cairan yang mengandung alkohol pada suhu kurang dari $60^{\circ} \mathrm{C}$ akan menyala apabila kontak dengan api, melalui geseran terjadi kebakaran misalnya: bensin; (c) bahan bersifat reaktif, bahan ini dalam keadaan normal tidak stabil dapat menyebabkan perubahan tanpa ledakan, dapat bereaksi hebat dengan air dan menimbulkan ledakan pula, menghasilkan gas, uap atau asap beracun dalam jumlah membahayakan bagi kesehatan manusia. (M Hidayatuddin. ST, 2000: 5).

Empati lingkungan dalam kaitannya dengan B3 berupa pewarna cair batik adalah lingkungan hidup masyarakat artinya lingkungan sebagai tempat hidup berupa kesatuan ruang dengan sejumlah manusia yang berkelompok terjadi interaksi dengan semua benda saling menyesuaikan diri sehingga kesesuaian dengan suatu keteraturan sosial dan budaya.

Berdasarkan beberapa teori-teori yang dikemukakan di atas maka dapat disintesiskan: empati lingkungan disini adalah kecenderungan orang bertindak untuk memahami situasi, dengan kepedulian, mengerti, mampu mengendalikan diri, toleran artinya memiliki kepekaan sosial, ramah dan menyayangi, bersifat humanistik ,altruistik dengan hasrat dan gagasan untuk bertindak karena adanya ancaman bahaya terhadap masyarakat

Lingkungan lebih dikhususkan pada lingkungan hidup sosial masyarakat artinya lingkungan sebagai tempat hidup berupa kesatuan ruang dengan sejumlah manusia yang berkelompok terjadi interaksi dengan semua benda saling menyesuaikan diri, sehingga kesesuaian dengan suatu keteraturan sosial dan budaya.

\section{Kemampuan Kognitif}

Kognitif adalah proses mental lebih tinggi pada diri manusia sebagai aktivitas untuk memperoleh pengetahuan dan pemahaman atas segala sesuatu di lingkungan sekitarnya. Kata ini berasal dari bahasa Latin adalah "Cognoscore" yang artinya mengetahui (mengenal) sesuatu yang mengacu pada suatu proses pengolahan informasi(Aidan P. Moran, 1996: 6).

Kognitif merupakan kepercayaan seseorang tentang sesuatu yang didapatkan dari proses berpikir tentang seseorang atau sesuatu.

Menurut Psychology Kognitif mengartikan bahwa kemampuan kognitif dengan melalui pengamatan berkaitan dengan aktivitas mental dan pengolahan informasi, memori serta penerapan 
pengetahuan. Jean Piaget mengatakan proses pikiran adalah transduktif atau pralogis artinya untuk memunculkan kembali pengetahuan, kegiatan pikiran manusia merupakan interaksi yang terus menerus antara individu dan lingkungan.

Mengetahui dengan menggunakan pancaindera (melalui pengamatan) merupakan aktivitas disengaja yang dipengaruhi motivasi dan emosi (Aidan P. Moran, 1996: 6-7). Sedang aktivitas mental merupakan penalaran, pemecahan persoalan serta pembentukan konsep-konsep pengetahuan tentang hal yang sedang dikaji (Linda Davidoff, 1991: 374).

John P Dworetzky dalam telaah teorinya tentang kemampuan kognitif, ia mengatakan adapun kemampuan kognitif merupakan kegiatan mental yang termasuk merasa, berpikir dan pemecahan masalah. Berpikir (mind) sama halnya dengan pikiran(John P Dworetzky, 1988: 214).

Pada proses pemindahan informasi terbentuk ke dalam sistem kognitif yang dapat digunakan sebagai jawaban pertanyaan dan pemecahan masalah, sehingga seseorang dalam memutuskan sesuatu, otak harus memproses informasi yang diterima, dengan pertimbangan pentingnya fakta yang sedang dihadapinya. (Drew Western, 1996: 17)

Struktur kognitif pada suatu kegiatan mental dan cara merespon adanya pengalaman langsung dari lingkungan, yang secara fisik merupakan kelompok ingatan yang tersusun saling berhubungan mem-bentuk aksi dan strategi untuk memahami dunia sekitarnya.

Pendapat beberapa ahli Psychology mengatakan bahwa kemampuan kognitif adalah aktivitas mental dapat diklasifikasikan dalam tiga kecakapan yakni pengetahuan, merasa, dan memilih.

Pengelompokkan ini berdasarkan pada percaya bahwa pikiran yang menyusun pengalaman berdasarkan aturan. Oleh karena itu kehidupan mental adalah ditetapkan oleh sifat intrinsik pikiran itu sendiri. Seluk beluk berpikir, merasakan dan memilih akan berbeda pada situasi yang berbeda, tetapi orang masih memiliki pengalaman yang berhubungan dengan tiga kelas mental tersebut.

Pada proses pemindahan informasi terbentuk ke dalam sistem kognitif yang dapat digunakan sebagai jawaban pertanyaan dan pemecahan masalah, sehingga seseorang dalam memutuskan sesuatu, otak harus memproses informasi yang diterima, dengan pertimbangan pentingnya fakta yang sedang dihadapinya(Drew Western, 1996: 17)

Struktur kognitif pada suatu kegiatan mental dan cara merespon adanya pengalaman langsung dari lingkungan, yang secara fisik me-rupakan kelompok ingatan yang tersusun saling berhubungan membentuk aksi dan strategi untuk memahami dunia sekitarnya.

Tingkat kemampuan kognitif pada tiap orang adalah berbedabeda tergantung aktivitas kognitifnya. Bila seseorang sedang berfilsafat tentang dunia sosial, maka aktivitas kemampuan kognitif relatif tinggi, sebaliknya jika seseorang tidak sabaran maka kekuatan yang dikeluarkan sangat tinggi, sehingga untuk proses berpikir kecil, maka aktivitas kemampuan kognitif relatif rendah.

Berdasarkan beberapa teori-teori yang dikemukakan di atas, maka dapat disintesiskan: kemampuan kognitif adalah mempersoalkan cara pengamat memperoleh, mengenal, mengorganisasi, menyimpan, dan mengingat kembali dengan kecerdasan dan kesadarannya menerima informasi tentang kondisi alam lingkungan oleh bahan limbah pewarna batik cair pada wilayah pembuangan pada perairan sungai.

\section{Nilai budaya}

a. Nilai

Nilai merupakan inti dari pilihan moral, yang berkaitan dengan etika, dalam arti sempit nilai merupakan sesuatu yang dianggap "baik", "me-nyenangkan" atau "penting”, "manfaat”. Arti luas nilai merupakan semua yang dianggap baik, kewajiban, kebijakan, keindahan, kebenaran dan luhur. Nilai dipadangan sebagai metafisik/kepercayaan mikrokosmos tentang manusia, apa sebenarnya diri manusia itu dan tindakannya terhadap dirinya sendiri dan orang lain, sehingga mampu menilai untuk mengambil sikap dan menentukan perilakunya. Nilai berciri pada kelompok dan merupakan tolok ukur bathin individu. Tata nilai dalam masyarakat sebagai tata nilai kooperatif atau nilai sosial yakni: (a) kemanusiaan; (b) keamanan; (c) kenyamanan; (d) persamaan; (e) keselarasan; (f) efisiensi dan (g) kepraktisan (Triguna, 2000: 25-26).

Nilai adalah bagian dari etika moral yang menifestasinya dijabarkan dalam norma-norma sosial, sistem hukum, adat sopan santun yang berfungsi sebagai tata kelakuan untuk mengatur tata tertib kehidupan bermasyarakat. Adat istiadat menetapkan bagaimana seharusnya warga masyarakat bertindak tertib (Koentjoroningrat,1995: 18).

Ada berbagai jenis nilai yang merupakan motif dan pemandu perilaku manusia, jenis-jenis nilai itu adalah (1) nilai etika, yang menyangkut baik dan buruk mengenai perilaku manusia; (2) nilai estetika, berhubungan dengan keindahan, baik dan jelek; (3) nilai agama yang berhubungan dengan suruhan dan larangan Tuhan; dan (4) nilai sosial, menyangkut hubungan antar manusia dan pergaulan hidup (Abubakar Busro, 1989: 35).

Sebagai makhuk individual, ma-nusia memiliki ciri-ciri khas berbeda dan membedakan dari manusia yang lain. Sebagai makhluk sosial, manusia adalah bagian dari hidup bersama dengan manusia yang lain.

Sebagai produk sosial budaya, nilai merupakan pedoman perilaku yang diyakini baik, benar dan diagungkan serta memberikan keabsahan perilaku.

Sumber-sumber sosialisasi untuk penanaman nilai adalah keluarga, lingkungan sosial, lembaga-lembaga pendidikan, agama, tradisi/adat istiadat, media masa, kelompok-kelompok sebaya dan sebagainya.

Dengan mengetahui sumber-sumber penanaman nilai dapat diketahui kekuatan bertahannya nilai di dalam pribadi seseorang. Nilai hanya dapat dipahami jika dikaitkan dengan sikap dan tingkah laku (Taliziduhu Ndraha, 2003: 18).

Nilai seseorang dapat sama seperti nilai semua orang lainnya, sama dengan sebagian orang, atau tidak sama dengan semua orang lain. nilai selain mewakili keunikan individu, juga dapat mewakili suatu kelompok tertentu. Hal ini mulai mengarah kepada pemahaman nilai yang universal. Dalam perkembangannya, konsep nilai adalah bahwa setiap orang, di mana saja, memiliki nilai-nilai yang sama dengan derajat yang berbeda (menunjukkan penegasan terhadap konsep universalitas nilai).

\section{b. Budaya}

Perkataan budaya atau kebuda-yaan=cultuur (bahasa Belanda)-=culture (bahasa Inggris) $=$ tsaqafah (bahasa Arab), berasal kata Latin cultura (kata kerja colo, colere) dan artinya memelihara, mengerjakan, mengolah, menyuburkan, mengembangkan. Dalam segi arti ini berkembanglah arti cultur sebagai "segala daya dan aktivitas manusia untuk mengolah dan mengubah alam”. Ditinjau dari segi bahasa Indonesia budaya atau kebudayaan berasal dari bahasa Sansakerta "buddhayah", yaitu bentuk jamak dari buddhi yang berarti budi atau akal (Joko Tri Prasetya, 1991: 28).

Koentjaraningrat mendefinisikan tentang budaya adalah keseluruhan pengetahuan manusia sebagai makhluk sosial yang digunakan untuk memahami lingkungan serta pe-ngalamannya, dan yang menjadi pedoman tingkah lakunya. Orang Jawa mendefinisikan budaya adalah hasil cipta, rasa dan karsa manusia, yang semuanya dimanfaatkan menurut karsanya(Selo Sumarjan,1978)

"Budi” berarti pengertian, akal, pikiran, ingatan (perasaan) hati, perasaan, maksud, cita, kearifan, (budi) pekerti, tabiat, watak, sifat Dari tinjauan definisi inilah diperoleh suatu definisi budaya terdiri dari pola-pola, eksplisit maupun implisit, tentang dan untuk perilaku yang diperoleh dan dipindahkan melalui simbol, membangun capaian yang pilah dari kelompok manusia, termasuk jelmaan dalam artifak, yang intinya terdiri dari gagasan-gagasan tradisional dan terutama nilai-nilai yang saling menyatu. Pengaruh 
nilai-nilai budaya berpengaruh pada sikap dan keyakinan dan perilaku masyarakat (Sutisna, 2001 : 223).

Menurut Carol R Ember budaya adalah adat kebiasaan yang didefinisikan sebagai belajar dalam bentuk penyebaran dari berperilaku, pikiran dan perasaan (Carol R Ember, 1988: 78).

Sedangkan menurut Leon G Shiffman mengatakan budaya adalah keseluruhan total dari belajar, keyakinan, nilai dan adat yang mengatur masyarakat.

Alex Thio menganalisis budaya adalah merupakan bentuk kehidupan atau adanya kesamaan dari keseluruhan yang kompleks terdiri dari objek, nilai, dan karakter lain pada orang serta suatu pola rancangan untuk kehidupan dari pendapat anggota masyarakat (Alex Thio, 1992: 56).

David Loudon mengkaji pula bahwa budaya adalah keseluruhan yang kompleks meliputi pengetahuan keyakinan, seni, moral, hukum, pakaian dan beberapa yang lain mengenai kesanggupan dan kebiasaan memperoleh sesuatu. Ada beberapa karakteristik untuk menggambarkan sifat istimewa dari budaya adalah sebagai: (1) penciptaan: orang menciptakan budaya mereka atas dasar tiga sistem yang saling ketergantungan yakni: (a) ediologi sistem atau komponen mental yang berisi pendapat (ide), keyakinan, nilai dan jalan sebagai alasan orang untuk belajar apa yang keinginan yang diperlukan; memberi kebahagiaan dan ketekunan: dalam memenuhi kebutuhan dasar biologis dan kebutuhan belajar dibutuhkan kesenangan sebagai elemen budaya yang diteruskan dari generasi ke generasi, jadi orang senang me-ngerjakan sesuatu dengan tekun; (2) adaptasi: budaya mengalami perubahan yang terus menerus, masyarakat berusaha mengikuti perubahan yang sangat dinamik dari perubahan budaya: (3) organisasi yang terintegrasi: budaya adalah kebersamaan yang memiliki elemen yang tidak konsisten (keadaan tidak tetap).

Berbagai definisi budaya oleh ahli antropologi, sosiologi, psikologi, filsafat dan lain-lain. Oleh A Kroeber dan C Kluchon dalam karangan itu berbagai-bagai definisi budaya terbagi dalam enam golongan. Golongan-golongan yaitu: (1) mengandung definisi yang luas, budaya adalah keseluruhan kompleks, yang terjadi dari unsur-unsur yang berbeda seperti pengetahuan, kepercayaan, seni dan hukum, moral, adat istiadat dan segala kecakapan yang lain, yang diperoleh manusia sebagai anggota masyarakat; (2) menekankan budaya sebagai warisan sosial atau tradisi; (3) budaya yang bersifat normatif, artinya budaya dipandang sebagai aturan dan jalan hidup manusia, golongan ini menekankan cita-cita, nilai dan kelakuan; (4) budaya adalah pendekatan kebudayaan secara psikologi, budaya dianggap sebagai penyesuaian manusia kepada lingkungan sekitarnya; (5) budaya bersifat struktur yang membicarakan pola-pola dan budaya organisasi; (6) budaya sebagai hasil perbuatan atau kecerdasan manusia. Pada manusia semua kegiatan oleh olah rasa dan olah tindak dipengaruhi oleh olah otak. Otak manusia dikaruniakan Tuhan untuk mempresepsi apa yang dia lihat, dia rasakan dari seluruh pengalaman dengan lingkungan tempat dia hidup. Persepsi bersumber dari latar belakang kehidupan manusia yakni kebudayaan yang mengajarkan kepadanya kesadaran untuk mencipta, merasa dan mengkarsa.

Kebudayaan hasil cipta, rasa dan karsa manusia yang turut menentukan persepsi manusia (Alo Liliweri, 111-112).

Menurut kategori konsep budaya menjadi enam kategori tersebut di atas adalah: (1) definisi deskriptif; (2) definisi historis; (3) definisi normatif; (4) definisi psikologis; (5) definisi struktural dan (6) definisi genetik (John W.Berry, Ype H. Pooringa, Marshall Segall, Pierre R. Dasen,1999: 325-326).

Budaya yang dimaksudkan adalah bawaan sosial umat manusia, merupakan bagian perbuatan manusia yang berasal dari lingkungan. Lebih rinci budaya adalah: (1) keseluruhan cara hidup suatu masyarakat; (2) warisan sosial yang diperoleh individu dari kelompoknya; (3) suatu cara berpikir, merasa dan percaya; (4) suatu abstraksi dari tingkah laku; (5) suatu gudang untuk mengumpulkan hasil belajar; (6) seperangkat orientasi standard pada masalah yang sedang berlangsung; (7) tingkah laku yang dipelajari; (8) suatu mekanisme untuk penataan tingkah laku yang bersifat normatif; (9) seperangkat teknik untuk menyesuaikan diri baik dengan lingkungan maupun sosial; (10) suatu endapan sejarah.

Dampak budaya begitu alami dan otomatis, pengaruh ini memberikan tanggapan pada budaya perilaku orang (Leon G Shiffman, Leslie Lazar Kanuk, 1990: 474).

Nilai dan budaya adalah nilai yang ada dan berkembang di dalam kehidupan manusia di lingkungan ataupun daerah kebudayaan tertentu. Sebagai produk lingkungan sosial budaya.

Nilai budaya adalah konsep yang bersifat fundamental yang berhubungan dengan normatif kognitif, konatif, dan efektif (Kluckorhn dan Strodbeck dalam Carter,1991: 164-172). Normatif kognitif berkenaan dengan pemikiran tentang life and universe; konatif berkenaan dengan selection of a particular course of action; dan afektif berkenaan dengan what is felt as important and desirable.

Nilai budaya merupakan kekhasan dimana dalam anggota kelompok menganggap penting dan diinginkan sebagai pedoman individuindividu anggota kelompok berperilaku (Kluckhohn dan Strodbeck 1991: 164-172).

Nilai budaya adalah nilai-nilai yang kerap kali menunjukkan kebutuhan dasar (mutlak) dalam hak dan kewajiban, sehingga dijunjung tinggi serta berlaku dalam kehidupan sosial budaya masyarakat pada umumnya sehingga dengan demikian nilai budaya dapat terbatasi persoalan yang dihadapi oleh manusia, serta dapat dijadikan acuan untuk mengatasi persoalan yang dihadapi oleh manusia, khususnya anggota kelompok ma-syarakat dalam lingkungan ke-budayaan. (Andre Benoit dalam Kaswardi, 1993)

Nilai budaya, merupakan bagian sistem budaya disamping norma-norma etik (Simuh. Sufisme Jawa, 1995: 58). Nilai budaya berupa gagasan-gagasan yang dipandang sangat berharga bagi proses berlangsungnya kehidupan, dengan ruang lingkup nilai budaya yang sangat luas, walaupun eksistensinya bersifat kabur, namun secara emosional disadari secara utuh.

Adapun ciri-ciri kepribadian yang dimanifestasikan dalam bentuk peri-laku atas pengaruh dominasi suatu nilai budaya itu dideskripsikan sebagai berikut: (1) Perilaku dasar manusia dari kepribadian yang dipengaruhi dominasi ilmu pengetahuan pada adalah berpikir, dengan wujud ingin belajar/serba ingin tahu, hasrat akan pengetahuan besar, logis, rasional, obyektif, cinta kebenaran, teoretik, dan individualis; (2) Perilaku dasar manusia dari kepribadian yang dipengaruhi dominasi nilai budaya ekonomi adalah bekerja/aktif, dengan wujud senang bekerja, bergagasan praktis, berorientasi pada prestasi kerja, memperjuangkan hidup, mengejar kekayaan/harta, egosentrik, dan kikir; (3) Perilaku dasar manusia dari kepribadian yang dipengaruhi dominasi nilai budaya estetis (seni) adalah menikmati/menghayati, dengan wujud hidup bersahaja, impressionist, ekspresionist subjektif, berorientasi pada makna hidup, senang memuja, menuju keselarasan batin, menuju keselarasan/ketenteraman hidup, dan molralis; (5) Perilaku dasar manusia dari kepribadian yang dipengaruhi dominasi nilai budaya sosial, adalah berbakti, dengan wujud cinta kasih pada sesama, senang berkorban, mengabdi kepentingan umum, dan pandai bergaul; dan (6) Perilaku dasar manusia dari kepribadian yang dipengaruhi dominasi nilai budaya poiltik adalah ingin berkuasa, dengan wujud mendominasi/menguasai manusia lain, kurang mencintai kebenaran, dan memaksakan kehendak/nilai pada orang lain.

Berdasarkan beberapa teori-teori yang dikemukakan di atas, maka dapat disintesiskan: nilai budaya adalah ide, konsep tentang sesuatu yang dianggap baik, bagaimana masyarakat mengapresiasi atau penghargaan terhadap lingkungan, serta pentingnya pada orang untuk berperilaku dan berinteraksi dengan objek di luar dirinya dengan menggunakan perasaannya, yang mengatur keseluruhan cara hidup suatu masyarakat sebagai realisasi kebiasaan dalam kehidupan sehari-hari. Suatu cara mengapresiasi, berkeyakinan, merasa dan percaya pada Allah, merupakan suatu abstraksi dari tingkah laku, seperangkat orientasi standard pada masalah yang sedang berlangsung, suatu mekanisme untuk penataan tingkah laku 
yang bersifat normatif, seperangkat teknik untuk menyesuaikan diri baik dengan lingkungan maupun sosial dan suatu endapan sejarah.

\section{Gaya Hidup}

Gaya hidup didefinisikan sebagai pola tingkah laku seharihari masyarakat. (Kamisa, 1986: 186) Pola tingkah laku ini tercermin dalam perilaku dari berbagai kejadian untuk perilaku dari berbagai aspek untuk jangka waktu yang panjang. Gaya hidup seseorang juga bisa dilihat pada apa yang disenanginya dan disukainya, maka sikap dan perilakunya mencerminkan gaya hidupnya (Sutisna,2002: 137).

Gaya hidup pada pengetahuan manusia modern yang konsepnya disusun berdasar pada: (a) sosiologi oleh Max Weber menyatakan bahwa gaya hidup suatu tanda status dalam masyarakat atau di dalam ke-lompoknya, (b) psychology oleh Alferd Adler menyatakan bahwa gaya hidup adalah usaha beradaptasi pribadi atas keberadaan individu terhadap lingkungannya (Bernard Cathelat, 1993: 82-83).

James $\mathrm{F}$ Engel mendefinisikan gaya hidup adalah sebagai pola kehidupan seseorang dalam menggu-nakan waktu dan uangnya. Gaya hidup disini mencerminkan aktivitas (A), ketertarikan (I) dan opini (O) orang pada suatu obyek. Orang menggunakan gaya hidup untuk menga-nalisis peristiwa yang terjadi di sekitar diri mereka untuk menafsirkan, menginterprestasikan, memprediksi peristiwa yang terjadi dan nilai kepribadian karena perubahan lingkungan (James F. Engel, Roger D. Black Wele, Paul W Minard, 1995: 448-449).

Penjelasan Redfield bahwa gaya hidup ditandai oleh seperangkat sikap dan nilai adalah sebagai berikut: (a) sikap yang mencari faedah (utilitarian); (b) penonjolan segi perasaan; (c) mengutamakan kesejahteraan hidup, karena orang lebih suka mengejar kesenangan dan menghindari kesakitan (Hedoisme). (James Danandjaja, 1988: 46-47).

David Loudon menggambarkan secara unik gaya hidup sangat dipengaruhi oleh pola kehidupan dan pencerminan pada perilaku konsumsi dalam kehidupan sehari-hari yakni: (1) bagaimana orang menggunakan waktu mereka untuk keperluan aktivitasnya; (2) apakah sebagian besar ketertarikan atau apa yang terpenting bagi pemenuhan kebutuhannya; dan (3) opini dan gambaran diri mereka serta dunia mereka. Bersama-sama tiga daerah adalah secara umum menunjuk pada Aktivitas (A), Ketertarikan (interest) (I) dan Opini (O) atau mudahnya disingkat AIO, sebagai pertanyaan untuk pengumpulan informasi tentang gaya hidup (David Loudon, Albert J Della Bitta, 1988: 118).

Terdapat tujuh kriteria aktivitas menurut Mc Dougall adalah: (1) spontanitas dari gerakan; (2) aktivitas tetap yang sedang berlangsung dari beberapa prakarsa stimulus; (3) variasi dalam gerakan langsung; (4) akhir dari persepsi yang sedang berlangsung dari perubahan situasi; (5) persiapan untuk situasi baru; (6) kapasitas perbaikan dengan latihan; (7) refleksi keseluruhan reaksi organ (James F Breman, 1991: 175).

Klasifikasi gaya hidup diukur berdasarkan pengukuran psychografik yang dikembangkan pada masing-masing dimensi (aktivitas, interest, opini/AIO) adalah berhubungan dengan kognitif orang. Psikografi memberikan pengukuran kuantitatif dengan sampel besar seperti telah didentifikasi oleh Plummer dalam "the Concept and Aplication of Life Style Segmentation" dalam journal of Marketing yang dikembangkan pada masing-masing demensi AIO seperti telah diidentifikasikan oleh Plummer dalam Assael 1992.

Motif kognitif yang menekankan pada proses informasi agar konsumen batik dapat beradaptasi dengan lingkungannya. Macam motif kognitif adalah: (a) konsistensi: orang menerima hubungan positip antara jenis barang dan kegunaan, maka persepsi terhadap barang menjadi konsisten dengan pemanfaatan pemakaian; (b) atribut: orientasi seseorang kearah kejadian eksternal dalam lingkungan, maka terjadi dorongan untuk merencanakan apa sebab akibat itu terjadi atau mengetahui sebab kejadian; (c) kategorisasi: menghadapi lingkungan yang kompleks, orang mengkategori- sasikan pengalamannya untuk mendapatkan kembali dari memorinya; (d) stimulasi: orang secara alamiah mempunyai peran ingin tahu dan mencoba mendapatkan sesuatu yang baru, perilaku inovatif konsumen menyebabkan untuk mencoba produk baru; (e) teleologis: secara konstan orang membandingkan dengan pikirannya menghendaki situasi berdasarkan persepsi yang ada sekarang, mencoba membuat situasi yang nyata menjadi sesuatu yang mungkin untuk pikirannya (AA Prabu Mangkunegara, 1988: 11).

Kebutuhan inti (core needs) yang berkaitan dengan perilaku yakni: (a) kebutuhan akan eksistensi mencakup semua tipe keinginan fisiological dan material; (b) kebutuhan yang berhubungan dengan sosial berkisar pada kebutuhan untuk memiliki hubungan berarti dengan pihak lain, dan (c) kebutuhan akan pertumbuhan dan memanfaatkan kemampuan hingga mencapai potensi yang maksimal J Winardi, 2001: 78-79).

Timbulnya kebutuhan pada dasarnya bersifat fisik dan kebutuhan pokok yakni kebutuhan yang bersifat fisiologis, sedang kebutuhan psikologis berbeda individu satu dengan individu yang lain, kebutuhan psikologis diperoleh dari lingkungan, yaitu kemampuan memperoleh makanan dari titik tersebut akan memperoleh keselamatan dan motif sosial antara lain cinta kasih menggabungkan diri dengan adanya rasa kepastian tentang kebutuhan untuk aktualisasi diri.

Berdasarkan beberapa teori dikemukakan di atas maka dapat di-sintesiskan: gaya hidup merupakan pola tingkah laku sehari-hari masya-rakat dalam menggunakan waktu dan uangnya yang mencerminkan: (1) aktivitas (2) Interest dan (3) opini disingkat dengan AIO dan ditandai oleh sikap dan nilai. Sikap dan nilai adalah sebagai berikut: (a) sikap yang mencari faedah (utilitarian); (b) penonjolan segi perasaan; (c) mengutamakan ke-sejahteraan hidup, karena orang lebih suka mengejar kesenangan dan menghindari kesakitan (Hedoisme). (Hedoisme (Internet Encyclopedia of Philosophy)

Pertama, sikap yang terdiri dari kognitif (keyakinan), emosional (pe-rasaan) dan perilaku (tindakan). Sikap diukur berdasar 5 (lima) motif kognitif: (1) konsistensi; (2) atribut; (3) kate-gorisasi;(4) stimulasi dan (5) teleologis.

Ke dua, aspek nilai yaitu: (1) outer directed, (2) need driven dan (3) inner directed.

Ke tiga motivasi berdasar pada: (1) kebutuhan fisik (dasar); (2) kebutuhan pykhis; (3) kebutuhan cinta; (4) kebutuhan penghargaan; (5) kebutuhan aktualisasi diri.

Ke empat, variabel kelas sosial dikelompokkan dengan cara: (1) variabel ekonomi yang menyangkut pekerjaan, pendapatan dan kekayaan; (2) variabel interaksi: prestise pribadi, asosiasi, dan sosialisasi. Ke empat aspek demografi yaitu: (1) usia, (2) pendidikan, (3) pendapatan, (4) pekerjaan ukuran besar keluarga, (5) tempat tinggal, (6) geografi, (7) besar kota, (8) keadaan lingkungan.

\section{KERANGKA BERPIKIR}

\section{Hubungan Kemampuan Kognitif dengan Empati} Lingkungan

Empati dalam hubungannya dengan lingkungan hidup pada pemikiran orang tentang bahaya bahan pewarna batik berdasarkan atas kemampuan mengenal, pengetahuan dan kesadaran, serta pengertian ten-tang bahaya B3 yang dihasilkan oleh hasil buangan bahan pewarna batik. Maka timbul keinginan untuk melakukan upaya tindakan agar dan membebaskan lingkungan dari bahan pencemar pewarna batik yang dibuang pada area sungai, dan orang akan berpikir karena pengetahuannya serta pemahamannya terhadap lingkungan dan pengalaman sosial.

Orang akan bertindak untuk memahami situasi, dengan kepedulian, mengerti, mampu mengendalikan diri (dengan perasaan paling dalam), toleran artinya memiliki kepekaan sosial, ramah dan menyayangi, bersifat humanistik (altruistik). dengan hasrat dan gagasan untuk bertindak karena adanya ancaman bahaya yang jelas terhadap masyarakat terkena dampak limbah batik pada wilayah sungai, sifat beracun berbahaya dari pewarna sintetik yang masuk ke sumur penduduk, sehingga tidak layak untuk keperluan sehari- 
hari. Dalam beberapa situasi orang pasti berpikir bahwa pengotoran lingkungan oleh limbah pewarna batik telah banyak dilakukan oleh para industri.

Dari uraian tersebut di atas maka diduga ada hubungan positif antara kemampuan kognitif dengan empati lingkungan masyarakat di wilayah pembuangan limbah batik ke sungai . Dengan kata lain makin tinggi kemampuan kognitif seseorang, akan semakin baik empati lingkungannya.

\section{Hubungan Nilai Budaya dengan Empati Lingkungan}

Empati lingkungan dalam kaitannya dengan limbah dari pewarna cair batik adalah lingkungan hidup masyarakat artinya lingkungan sebagai tempat hidup berupa kesatuan ruang dengan sejumlah manusia yang berkelompok di sepanjang sungai buangan limbah batik, terjadi interaksi dengan semua benda saling menyesuaikan diri sehingga kesesuaian dengan suatu keteraturan sosial dan budaya. Dalam lingkungan sosial ini norma-norma umum sangsi berlaku sebagai kontrol serta membentuk suatu sistem nilai.

Bagaimana masyarakat menga-presiasi lingkungan dan berperilaku serta berinteraksi dengan objek di luar dirinya dengan menggunakan pe-rasaannya, yang mengatur keseluruhan cara hidupnya, sebagai realisasi kebiasaan dalam kehidupan sehari-hari.

Dari uraian tersebut di atas maka diduga ada hubungan positif antara nilai budaya dengan empati lingkungan masyarakat di wilayah pembuangan limbah batik ke sungai. Dengan kata lain makin tinggi nilai budaya seseorang, akan semakin baik empati lingkungannya.

\section{Hubungan Gaya Hidup dengan Empati Lingkungan}

Gaya hidup adalah Gaya hidup disini mencerminkan aktivitas (A), ketertarikan/Interest (I) dan opini (O) orang pada suatu obyek lingkungan toksik. Pola tingkah laku sehari-hari merupakan aktivitas (kegiatan, keinginan) dan pendapat yang ditandai oleh sikap nyata, dari nilai tertentu yang berkaitan dengan keyakinan, perasaan dan tindakan

Gaya hidup seseorang menunjukkan kemampuan untuk menganalisis peristiwa yang terjadi di se-kitar diri mereka dapat menafsirkan, menginterprestasikan, memprediksi suatu peristiwa terjadi pencemaran lingkungan.

Dari uraian tersebut maka, diduga ada hubungan positif antara gaya hidup dengan empati lingkungan. Dengan kata lain makin tinggi gaya hidup masyarakat, akan semakin baik empatinya lingkungannya.

\section{Hubungan Kemampuan Kognitif, Nilai Budaya dan Gaya} Hidup secara bersama-sama dengan Empati Lingkungan

Perasaan keinginan untuk menolong tanpa pamrih dan membebaskan lingkungan karena masyarakat tidak acuh tak acuh terhadap lingkungannya sendiri untuk menuju lingkungan sehat sehingga terwujudlah lingkungan sehat yang akan mempengaruhi kesehatan manusia.

Norma-norma budaya bagi peri-laku prososial empati yaitu untuk menghindari ketidak adilan lebih banyak dengan mengubah situasi yang sedang berlangsung. Norma-norma ini adalah: (1) tanggung jawab sosial; (2) timbal balik; dan (3) keadilan sosial.

Kemampuan kognitif adalah pikiran yang terjadi dari kehalusan susunan pikiran perasaan, pembukaan serta perluasan pemikiran. Sehingga dari terbukanya pemikiran maka menimbulkan pengetahuan, pengenal-an, pengakuan, kesadaran, pengertian, pengambilan keputusan, pemecahan masalah, cara membuat pilihan dan pengambilan keputusan

Dari uraian tersebut maka, diduga ada hubungan positif antara kemampuan kognitif, nilai budaya dan gaya hidup secara bersama-sama dengan empati lingkungan. Dengan kata lain makin tinggi antara kemampuan kognitif, nilai budaya dan gaya hidup masyarakat secara bersama-sama, akan semakin baik empati lingkungannya.

\section{PENGAJUAN HIPOTESIS}

Berdasarkan deskripsi teoritik dan kerangkan berpikir di atas, dapat diajukan hipotesis penelitian ini sebagai berikut:

1. Terdapat hubungan positif kemam-puan kognitif dengan empati Lingkungan. Dengan kata lain semakin tinggi kemampuan kognitif, akan semakin baik pula empati lingkungan.

2. Terdapat hubungan positif nilai budaya dengan empati Lingkungan. Dengan kata lain makin nilai budaya masyarakat, akan semakin baik pula empati Lingkungan.

3. Terdapat hubungan positif gaya hidup dengan empati lingkungan. Dengan kata lain makin gaya hidup masyarakat, akan semakin baik pula empati lingkungan.

4. Terdapat hubungan positif secara bersama-sama antara kemampuan kognitf, nilai budaya dan gaya hidup dengan empati terhadap masyarakat di area pembuangan limbah batik. Dengan kata lain makin tinggi kemampuan kognitif, gaya hidup, dan nilai budaya masyarakat semakin baik pula empati lingkungannya.

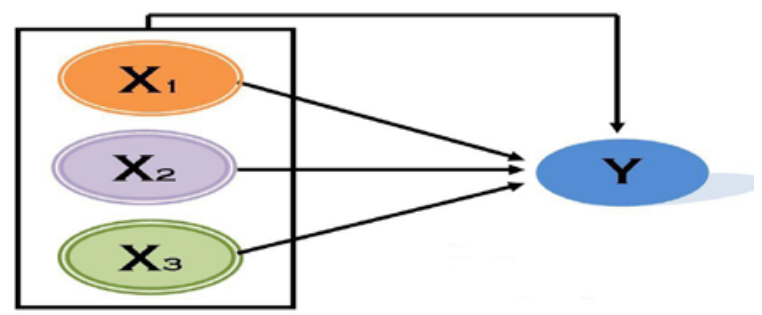

Gambar 2: Model Hubungan antara Variabel Terikat dengan Variabel Bebas

Keterangan:
$\mathrm{Y}$
$\mathrm{X}_{1}$
: Empati Lingkungan (Variabel Terikat)
$\mathrm{X}_{2}$
: Kemampuan Kognitif (Variabel Bebas)
$\mathrm{X}_{3}$
: Nilai Budaya (Variabel Bebas)
: Gaya Hidup (Variabel Bebas)

\section{METODOLOGI PENELITIAN}

Tujuan penelitian ini adalah untuk memperoleh gambaran tentang empati lingkungan masyarakat kota batik Surakarta dalam kaitannya konservasi lingkungan oleh limbah pewarna batik. Masyarakat yang diteliti adalah masyarakat yang tinggal di area pingiran sungai pembuangan limbah batik. Penelitian ini dilakukan di Kota Batik Surakarta. Populasi adalah masyarakat yang ada di 3 Kecamatan, yakni Kecamatan Banjarsari, Ke-camatan Laweyan dan Kecamatan Jebres yang berjumlah 150 orang.Teknik pengambilan sampel secara Multi Stage Random Sampling artinya cara pengambilan sampel yang dilakukan secara bertahap. Tahap-tahap pengambilan sampel dalam penelitian ini adalah sebagai berikut : pertama adalah pengambilan sampel terhadap kepala rumah tangga yang berada di wilayah 3 kecamatan terpilih, yakni Kecamatan Jebres, Kecamatan Banjarsari dan Kecamatan Laweyan. Dengan demikian sampling pada tahap I adalah 3 kecamatan. Kedua setelah ditetapkan 3 kecamatan dari 5 kecamatan yang ada di kota Surakarta, selanjutnya setiap masing-masing kecamatan diambil 2 kelurahan secara random. Dengan demikian sampling pada tahap II adalah 6 kelurahan. Ketiga kegiatan sampling selanjutnya adalah mengambil 1 RW dari setiap kelurahan yang terpilih. Dengan demikian sampling pada tahap III adalah 6 RW dari 6 kelurahan. Ke-empat Kegiatan sampling selanjutnya adalah mengambil 1 RT dari setiap RW yang terpilih. Dengan demikian sampling pada tahap IV adalah 6 RT dari 6 RW. Kelima kegiatan sampling selanjutnya adalah mengambil 1 RT dari setiap RW yang terpilih. Dengan demikian sampling pada tahap V adalah 6 RT dari 6 RW. Keenam tahap terakhir adalah melakukan sampling untuk memilih 25 kepala rumah tangga dari setiap RT. Dengan demikian sampling pada tahap VI (akhir) adalah 150 kepala rumah tangga dari 6 RT atau jumlah keseluruhan sampel yang diambil adalah 150 responden kepala 
rumah tangga. Untuk mengumpulkan data tentang kemampuan kognitif, nilai budaya, gaya hidup dan empati lingkungan digunakan intrumen dalam bentuk angket dengan lima skala.Instrumen kemampuan kognitif digunakan tes pilihan ganda biasa. Option yang digunakan dalam angket tentang nilai budaya, empati lingkungan sangat setuju, setuju, ragu-ragu, tidak setuju dan sangat tidak setuju.

Adapun angket yang digunakan dalam angket tentang nilai budaya dan empati lingkungan jawabannya alternatif bila menjawab positif nilainya 5-1 sedangkan negatif 5-1 juga untuk menentukan reliabilitas instrumen ini digunakan Rumus Alpha Cronbach. Hasil perhitungan diperoleh reliabilitas instrumen empati lingkungan sebesar 0,9267, realibilitas instrumen kemampuan kognitif sebesar 0,9464 , realibilitas instrumen nilai budaya sebesar 0,8741, realibilitas instrumen gaya hidup sebesar 0,9267.

\section{HASIL PENELITIAN DAN PEM-BAHASAN}

Jumlah responden pada penelitian ini sebanyak 150 orang. Jumlah ini jumlah bersih kuesioner profil responden berdasarkan identitas dirinya adalah sebagai berikut: pekerjaan responden atau sampel semuanya swasta dan PNS. Latar belakang pendidikan responden terdiri atas: SD, SMP, SMA dan Sarjana. Deskripsi data dari setiap variabel penelitian memiliki kecenderungan memusat (mean, median, modus), dan ukuran keragaman (range, simpangan baku, distribusi frekuensi dan histogram).

\section{Empati Lingkungan}

Data empati lingkungan masyarakat kota Surakarta berupa data primer setelah diolah menghasilkan deskripsi data bahwa 88 responden sebagai skor terendah, sampai ke angka 136 sebagai skor tertinggi. Dari sebaran nilai tersebut, dihasilkan skor rerata 113,26; median 112,50; dan modus 112,00; sedangkan simpangan bakunya sebesar 9,35 varians 87,37 .

\section{Kemampuan Kognitif}

Data kemampuan kognitif masyarakat kota Surakarta berupa data primer setelah diolah menghasilkan deskripsi data bahwa skor terendah yang diperoleh adalah 6 dan skor tertingginya 30. Dari sebaran data tersebut diperoleh harga rata-rata 20,84; median 21; dan modus ; sedangkan simpangan baku diperoleh 5,36 dengan varians 28,752 .

\section{Nilai Budaya}

Data kemampuan kognitif masyarakat kota Surakarta berupa data primer setelah diolah menghasilkan deskripsi data bahwa dari 97 hingga 150, masing-masing sebagai skor terendah dan skor tertinggi. Dari sebaran data itu didapat harga rata-ratanya sebesar 122,11; median 122,00; dan modus 112,00 sedangkan simpangan baku sebesar 10,75 dengan varians 115,51.

\section{Gaya Hidup}

Data gaya hidup masyarakat kota Surakarta berupa data primer setelah diolah menghasilkan deskripsi data bahwa dari 95 dan skor tertinggi sebesar 150. Harga rata-rata sebesar123,26; median sebesar 123,00; modus 120,00, sedangkan simpangan Bakunya diperoleh 12,86. dapat dilihat pda Tabel 1 di bawah ini.
Tabel 1. Deskripsi Data

\begin{tabular}{|l|c|c|c|c|}
\hline $\begin{array}{c}\text { Variabel } \\
\text { Sttk Das }\end{array}$ & $\begin{array}{c}\text { Empati } \\
\text { lingkungan }\end{array}$ & $\begin{array}{c}\text { Kemampuan } \\
\text { kognitif }\end{array}$ & $\begin{array}{c}\text { Nilai } \\
\text { budaya }\end{array}$ & Gaya hidup \\
\hline Rerata & 113,26 & 110,90 & 122,11 & 123,26 \\
\hline Std dvs & 9,35 & 13,78 & 10,75 & 12,86 \\
\hline SkorMaks & 138 & 138 & 150 & 150 \\
\hline Skor Min & 88 & 83 & 97 & 100 \\
\hline
\end{tabular}

Untuk menjawab hipotesis penelitian yang diajukan digunakan teknik analisis korelasi dan regresi. Hipotesis pertama, kedua dan ketiga menggunakan regresi dan korelasi sederhana.

Rumus korelasi yang digunakan adalah Pruduct Moment dari Pearson dan diuji dengan uji-t. Adapun hipotesis keempat dianalisis dengan regresi dan korelasi jamak melalui uji $\mathrm{F}$ dapat dilihat pda Tabel 2 di bawah ini.

Tabel 2. Ringkasan Hasil Analisis Uji Normalitas Galat Taksiran

\begin{tabular}{|c|c|c|c|c|}
\hline No. & $\begin{array}{c}\text { Galat Taksiran Y- } \\
\hat{\mathbf{Y}} \text { Berdasarkan } \\
\text { Persamaan }\end{array}$ & $\begin{array}{c}\mathbf{L}_{\mathbf{0}} \\
\text { terbesar }\end{array}$ & $\begin{array}{c}\mathbf{L}_{\text {tabel }} \\
(\boldsymbol{\alpha}=\mathbf{0 , 0 5 , n = 1 5 0 )}\end{array}$ & Kesimpulan \\
\hline 1 & $\hat{\mathrm{Y}}=90,039+$ & 0,0517 & 0,0723 & Normal \\
$0,209 \mathrm{X}_{1}$ & 0,0624 & 0,0723 & Normal \\
\hline 2 & $\begin{array}{c}\hat{\mathrm{Y}}=80,908+ \\
0,265 \mathrm{X}_{2}\end{array}$ & 0,0535 & 0,0723 & Normal \\
\hline 3 & $\begin{array}{c}\hat{\mathrm{Y}}=88,101+ \\
0,204 \mathrm{X}_{3}\end{array}$ & & \\
\hline
\end{tabular}

Ringkasan hasil uji homogenitas skor-skor $\mathrm{Y}$ berdasarkan kelompok skor $\mathrm{X}_{1}, \mathrm{X}_{2}$, dan $\mathrm{X}_{3}$ yang telah dipaparkan, dapat dilihat pda Tabel 3 di bawah ini

Tabel 3. Ringkasan Hasil Analisis Uji Homogenitas Varians Data Y Berdasarkan Pengelompokan Data $\mathrm{X}_{1}$, Data $\mathrm{X}_{2}$, dan Data $\mathrm{X}_{3}$

\begin{tabular}{|c|c|c|c|c|}
\hline No & $\begin{array}{c}\text { Varians } \\
\text { DataY } \\
\text { Dilihat } \\
\text { dari } \\
\text { Kelompok } \\
\text { Data }\end{array}$ & $\chi^{2}$ hitung & $\begin{array}{c}\chi^{2} \text { tabel } \\
(\boldsymbol{\alpha}=0,05)\end{array}$ & Kesimpulan \\
\hline 1 & $\mathrm{X}_{1}$ & $50,76^{\mathrm{ns}}$ & $60,48 \quad(\mathrm{dk}=44)$ & $\begin{array}{c}\text { Kelompok varians } \\
\text { Homogen }\end{array}$ \\
\hline 2 & $\mathrm{X}_{2}$ & $43,98^{\text {ns }}$ & $49,80 \quad(\mathrm{dk}=35)$ & $\begin{array}{c}\text { Kelompok varians } \\
\text { Homogen }\end{array}$ \\
\hline 3 & $\mathrm{X}_{3}$ & $38,75^{\text {ns }}$ & $59,31 \quad(\mathrm{dk}=43)$ & $\begin{array}{l}\text { Kelompok varians } \\
\text { Homogen }\end{array}$ \\
\hline
\end{tabular}

\section{Pengujian Hipotesis Penelitian}

Ada empat hipotesis yang diuji dalam penelitian ini, untuk mengetahui hubungan variabel bebas dan variabel terikat melalui teknik analisis regresi linier dan korelasional untuk mendapatkan koefisien korelasi kekuatan hubungan antara variabel bebas dan terikat. Tiga hipotesis di uji menggunakan regresi sederhana dan satu hipotesis diuji dengan menggunakan regresi ganda, dan akan diperoleh hubungan antara variabel bebas dengan variabel terikat.

Hipotesis pertama yang diujikan adalah terdapat hubungan positif antara empati lingkungan $(\mathrm{Y})$ dan kemampuan kognitif $\left(\mathrm{X}_{1}\right)$, hasil pengujian dapat dilihat pda Tabel 4 di bawah ini. 
Tabel 4. Daftar Analisis Varians untuk Menguji Keberartian dan Kelinearan Persamaan Regresi Sederhana $\hat{Y}=90,039+0,209 X_{1}$

\begin{tabular}{|l|c|c|c|c|c|c|}
\hline Sumber Varians & $\mathbf{d k}$ & $\mathbf{J K}$ & $\mathbf{K T}$ & $\mathbf{F}_{\text {hitung }}$ & $\begin{array}{c}\mathbf{F}_{\text {tabel }} \\
\boldsymbol{\alpha}=\mathbf{0 , 0 5}\end{array}$ & $\begin{array}{c}\mathbf{F}_{\text {tabel }} \\
\boldsymbol{\alpha}=\mathbf{0 , 0 1}\end{array}$ \\
\hline Total & 150 & 1937193 & - & - & - & \\
\hline Koefisien (a) & 1 & 1924174,140 & - & - & - & \\
\hline Regresi (b/a) & 1 & 1239,741 & 1239,741 & $15,577^{* *}$ & 3,95 & 2,066 \\
\hline Sisa & 148 & 11779,109 & 79,588 & - & - & - \\
\hline Tuna Cocok & 15 & 3776,984 & 251,799 & $1,535^{\text {ns }}$ & 2,78 & 1,945 \\
\hline Galat & 43 & 8002,125 & 186,096 & - & - & - \\
\hline
\end{tabular}

Derajat (kadar) kekuatan hubungan antara kemampuan kognitif $\left(\mathrm{X}_{1}\right)$ dan empati lingkungan io(Y) dijelaskan oleh harga koefisien korelasi $r_{y 1}$ sebesar 0,309. Pengujian keberartian terhadap koefisien korelasi yang telah diperoleh, dapat dilihat pda Tabel 5 di bawah ini.

Tabel 5. Hasil Analisis Uji Keberartian Koefisien Korelasi Sederhana $\mathrm{X}_{1}$ dan $\mathrm{Y}$

\begin{tabular}{|c|c|c|c|c|}
\hline \multirow{2}{*}{ Dk } & \multirow{2}{*}{$\boldsymbol{r}_{y 1}$} & $\boldsymbol{t}_{\text {hitung }}$ & \multicolumn{2}{|c|}{$\boldsymbol{t}_{\text {tabel }}$} \\
\cline { 4 - 5 } & & & $\boldsymbol{\alpha}=\mathbf{0 , 0 5}$ & $\boldsymbol{\alpha}=\mathbf{0 , 0 1}$ \\
\hline 148 & 0,309 & $3,96 * *$ & 1,63 & 2,67 \\
\hline
\end{tabular}

Pengujian keberartian/signifikansi koefisien korelasi parsial dengan pengontrolan variabel nilai budaya $\left(\mathrm{X}_{2}\right)$, dan gaya
Tabel 6. Hasil Analisis Uji Keberartian Koefisien Korelasi Parsial antara $\mathrm{X}_{1}$ dan $\mathrm{Y}$ dengan Pengontrol $\mathrm{X}_{2} ; \mathrm{X}_{3}$; dan $\mathrm{X}_{2} \mathrm{X}_{3}$ sekaligus

\begin{tabular}{|c|c|c|c|}
\hline $\begin{array}{c}\text { Koefisien Korelasi } \\
\text { Parsial }\end{array}$ & $\mathbf{t}_{\text {hitung }}$ & $\begin{array}{c}\mathbf{t}_{\text {tabel }} \\
\boldsymbol{\alpha}=\mathbf{0 , 0 5}\end{array}$ & $\begin{array}{c}\mathbf{t}_{\text {tabel }} \\
\boldsymbol{\alpha}=\mathbf{0 , 0 1}\end{array}$ \\
\hline $\mathrm{r}_{\mathrm{y} 1.2}=0,268$ & $3,36^{*}$ & 1,64 & 2,37 \\
\hline $\mathrm{r}_{\mathrm{y} 1.3}=0,333$ & $4,28^{*}$ & 1,64 & 2,37 \\
\hline $\mathrm{r}_{\mathrm{y} 1.23}=0,296$ & $3,74^{*}$ & 1,64 & 2,37 \\
\hline
\end{tabular}

Hipotesis kedua yang diujikan adalah terdapat hubungan positif antara empati lingkungan $(\mathrm{Y})$ dan nilai budaya $\left(\mathrm{X}_{2}\right)$ Untuk mengetahui keberartian (signifikansi) dan kelinearan (linearitas) persamaan regresi yang diperoleh, perlu dilakukan pengujian dengan menggunakan teknik analisis varians. Hasil pengujian itu dapat diringkaskan sebagaimana yang diperlihatkan pada Tabel 7 di bawah ini.

Tabel 7. Daftar Analisis Varians untuk Menguji Keberartian dan Kelinearan Persamaan Regresi Sederhana $\hat{\mathrm{Y}}=\mathbf{8 0 , 9 0 9}+\mathbf{0 , 2 6 5 \mathrm { X } _ { 2 }}$

\begin{tabular}{|l|c|c|c|c|c|c|}
\hline \multicolumn{1}{|c|}{ Sumber Varians } & $\mathbf{d k}$ & $\mathbf{J K}$ & $\mathbf{K T}$ & $\mathbf{F}_{\text {hitung }}$ & $\begin{array}{c}\mathbf{F}_{\text {tabel }} \\
\boldsymbol{\alpha = \mathbf { 0 , 0 5 }}\end{array}$ & $\begin{array}{c}\mathbf{F}_{\text {tabel }} \\
\boldsymbol{\alpha}=\mathbf{0 , 0 1}\end{array}$ \\
\hline Total & 150 & 1937193 & - & - & - & \\
\hline Koefisien (a) & 1 & 1924174,140 & - & - & - & \\
Regresi (b/a) & 1 & 1208,122 & 1208,122 & $15,139 *$ & 3,95 & 2,06 \\
Sisa & 148 & 11810,738 & 79,802 & - & - & - \\
\hline Tuna Cocok & 34 & 2975,126 & 87,504 & $1,129 * *$ & 1,524 & 1,81 \\
Galat & 114 & 8835,612 & 77,505 & - & - & - \\
\hline
\end{tabular}

Derajat (kadar) kekuatan hubungan antara nilai budaya $\left(\mathrm{X}_{2}\right)$ dan empati lingkungan $(\mathrm{Y})$ dijelaskan oleh harga koefisien korelasi $r_{y 2}$ sebesar 0,875.

Pengujian keberartian terhadap koefisien korelasi yang telah diperoleh, ditunjukkan oleh Tabel 8 di bawah ini.

Tabel 8. Hasil Analisis Uji Keberartian Koefisien Korelasi Sederhana $X_{2}$ dan $Y$

\begin{tabular}{|c|c|c|c|c|}
\hline \multirow{2}{*}{$\mathbf{d k}$} & \multirow{2}{*}{$\boldsymbol{R}_{\boldsymbol{y} \mathbf{2}}$} & \multirow{2}{*}{$\boldsymbol{t}_{\text {hitung }}$} & \multicolumn{2}{|c|}{$\boldsymbol{t}_{\text {tabel }}$} \\
\cline { 4 - 5 } & & & $\boldsymbol{\alpha}=\mathbf{0 , 0 5}$ & $\boldsymbol{\alpha}=\mathbf{0 , 0 1}$ \\
\hline 148 & 0,305 & $3,90^{* *}$ & 1,63 & 2,37 \\
\hline
\end{tabular}

Pengujian keberartian (signifikansi) koefisien korelasi parsial dengan pengontrolan variabel kemampuan kognitif $\left(\mathrm{X}_{1}\right)$, dan gaya hidup $\left(\mathrm{X}_{3}\right)$ baik secara sendiri-sendiri maupun secara simultan sekaligus disajikan pada Tabel 9 .

Tabel 9. Hasil Analisis Uji Keberartian Koefisien Korelasi Parsial antara $\mathrm{X}_{2}$ dan $\mathrm{Y}$ dengan Pengontrol $\mathrm{X}_{1} ; \mathrm{X}_{3}$; dan $\mathrm{X}_{1} \mathrm{X}_{3}$ sekaligus

\begin{tabular}{|c|c|c|c|}
\hline \multirow{2}{*}{$\begin{array}{c}\text { Koefisien Korelasi } \\
\text { Parsial }\end{array}$} & \multirow{2}{*}{$\boldsymbol{t}_{\text {hitung }}$} & \multicolumn{2}{|c|}{$\boldsymbol{t}_{\text {tabel }}$} \\
\cline { 3 - 4 } & $3,31^{* *}$ & 1,64 & $\begin{array}{c}\boldsymbol{t}_{\text {tabel }} \mathbf{\alpha}=\mathbf{0 , 0 5} \mathbf{0} \\
=\mathbf{0 , 0 1}\end{array}$ \\
\hline $\mathrm{r}_{\mathrm{y} 2.1}=0,263$ & 3,37 \\
\hline $\mathrm{r}_{\mathrm{y} 2.3}=0,255$ & $3,18^{* *}$ & 1,64 & 2,37 \\
\hline $\mathrm{r}_{\mathrm{y} 2.13}=0,202$ & $2,49^{* *}$ & 1,64 & 2,37 \\
\hline
\end{tabular}

Hipotesis ketiga yang diujikan adalah terdapat hubungan positif antara empati lingkungan $(\mathrm{Y})$ dan gaya hidup $\left(\mathrm{X}_{3}\right)$ Untuk mengetahui keberartian (signifikansi) dan kelinearan (linearitas) 
persamaan regresi yang diperoleh, perlu dilakukan pengujian dengan menggunakan teknik analisis varians. Hasil pengujian itu dapat diringkaskan sebagaimana yang diperlihatkan pada Tabel 10 dibawah ini.

Tabel 10. Daftar Analisis Varians untuk Menguji Keberartian dan Kelinearan

Persamaan Regresi Sederhana $\hat{Y}=88,101+0,204 X_{3}$

\begin{tabular}{|c|c|c|c|c|c|c|}
\hline Sumber Varians & $\mathbf{d k}$ & $\mathbf{J K}$ & $\mathbf{K T}$ & $\mathbf{F}_{\text {hitung }}$ & $\begin{array}{c}\mathbf{F}_{\text {tabel }} \\
\boldsymbol{\alpha}=\mathbf{0 , 0 5}\end{array}$ & $\begin{array}{c}\mathbf{F}_{\text {tabel }} \\
\boldsymbol{\alpha}=\mathbf{0 , 0 1}\end{array}$ \\
\hline Total & 150 & 1937193 & - & - & & \\
\hline Koefisien (a) & 1 & 1924174,140 & - & - & & \\
Regresi (b/a) & 1 & 1027,287 & 1027,287 & $12,679 *$ & 3,95 & 2,06 \\
Sisa & 148 & 11991,573 & 81,024 & - & & \\
\hline Tuna Cocok & 42 & 4259,675 & 101,421 & $1,390 * *$ & 1,63 & 1,77 \\
Galat & 106 & 7731,897 & 72,942 & - & & \\
\hline
\end{tabular}

Derajat (kadar) kekuatan hubungan antara gaya hidup $\left(\mathrm{X}_{3}\right)$ dan empati lingkungan $(\mathrm{Y})$ dijelaskan oleh harga koefisien korelasi $r_{y 3}$

sebesar 0,281. Pengujian keberartian terhadap koefisien korelasi yang telah diperoleh, ditunjukkan oleh Tabel 11 di bawah ini.

Tabel 11: Hasil Analisis Uji Keberartian Koefisien Korelasi Sederhana $\mathrm{X}_{3}$ dan $\mathrm{Y}$

\begin{tabular}{|c|c|c|c|c|}
\hline \multirow{2}{*}{$\mathbf{d k}$} & \multirow{2}{*}{$\boldsymbol{r}_{y 3}$} & \multirow{2}{*}{$\boldsymbol{t}_{\text {hitung }}$} & \multicolumn{2}{|c|}{$\boldsymbol{t}_{\text {tabel }}$} \\
\cline { 4 - 5 } & & $\mathbf{\alpha}$ & $\mathbf{0 , 0 5}$ & $\boldsymbol{\alpha}=\mathbf{0 , 0 1}$ \\
\hline 148 & 0,281 & $3,56^{* *}$ & 1,63 & 2,37 \\
\hline
\end{tabular}

Pengujian keberartian (signifikansi) koefisien korelasi parsial dengan pengontrolan variabel kemampuan kognitif $\left(\mathrm{X}_{1}\right)$, dan nilai budaya $\left(\mathrm{X}_{2}\right)$ baik secara sendiri-sendiri maupun secara simultan sekaligus disajikan pada Tabel 12 di bawah ini.
Tabel 12: Hasil Analisis Uji Keberartian Koefisien Korelasi Parsial antara $X_{3}$ dan $Y$ dengan Pengontrol $X_{1} ; X_{2}$; dan $X_{1} X_{2}$ sekaligus

\begin{tabular}{|c|c|c|c|}
\hline \multirow{2}{*}{$\begin{array}{c}\text { Koefisien Korelasi } \\
\text { Parsial }\end{array}$} & \multirow{2}{*}{$\boldsymbol{t}_{\text {hitung }}$} & \multicolumn{2}{|c|}{$\boldsymbol{t}_{\text {tabel }}$} \\
\cline { 3 - 4 } & & $\boldsymbol{\alpha}=\mathbf{0 , 0 5}$ & $\boldsymbol{\alpha}=\mathbf{0 , 0 1}$ \\
\hline$r_{y 3.1}=0,308$ & $3,91^{* *}$ & 1,64 & 2,37 \\
\hline$r_{y 3.2}=0,225$ & $2,80^{*}$ & 1,64 & 2,37 \\
\hline$r_{y 3.12}=0,259$ & $3,26^{*}$ & 1,64 & 2,37 \\
\hline
\end{tabular}

Hipotesis keempat yang diajukan dalam penelitian ini menyatakan bahwa terdapat hubungan positif antara kemampuan kognitif $\left(\mathrm{X}_{1}\right)$, nilai budaya $\left(\mathrm{X}_{2}\right)$, dan gaya hidup $\left(\mathrm{X}_{3}\right)$ secara bersama-sama dengan empati lingkungan(Y). Artinya, makin baik kemampuan kognitif, nilai budaya, dan gaya hidup, makin baik pula empati lingkungan masyarakat.

Hasil analisis regresi ganda terhadap pasangan data dari keempat variabel menghasilkan persamaan regresi tersebut di atas. Untuk mengetahui keberartian (signifikansi) persamaan regresi yang diperoleh tersebut, perlu dilakukan pengujian dengan menggunakan teknik analisis varians. Hasil pengujian itu dapat dilihat pda Tabel 13 di bawah ini.

Tabel 13: Daftar Analisis Varians untuk Menguji Keberartian Persamaan

Regresi Jamak $\hat{Y}=49,657+0,191 X_{1}+0,167 X_{2}+0,179 X_{3}$

\begin{tabular}{|c|c|c|c|c|c|c|}
\hline Sumber Varians & $\mathbf{D k}$ & $\boldsymbol{J K}$ & $\boldsymbol{R J K}$ & $\mathbf{F}_{\text {hitung }}$ & $\begin{array}{c}\mathbf{F}_{\text {tabel }} \boldsymbol{\alpha}= \\
\mathbf{0 , 0 5}\end{array}$ & $\begin{array}{c}\mathbf{F}_{\text {tabel }} \boldsymbol{\alpha} \\
\mathbf{= 0 , 0 1}\end{array}$ \\
\hline Total & 150 & 1937193 & - & - & - & - \\
\hline Koefisien $\left(\mathrm{b}_{0}\right)$ & 1 & 1924174,140 & - & - & - & - \\
Total Dikoreksi & 149 & 13018,860 & - & - & - & - \\
\hline Regresi & 3 & 2791,381 & 930,460 & $13,128 * *$ & 2,67 & 3,91 \\
Sisa & 146 & 10227,479 & 70,05 & - & - & - \\
\hline
\end{tabular}

Tabel 13 di atas memperlihatkan bahwa $F_{\text {hitung }}$ sebesar 13,128 jauh lebih besar daripada $F_{\text {tabel }}$ pada taraf nyata $\alpha=0,01$ sebesar 3,91. Hal ini menunjukkan bahwa model persamaan regresi jamak tersebut, secara statistik, sangat berarti (signifikan). Derajat (kadar) kekuatan hubungan antara kemampuan kognitif $\left(\mathrm{X}_{1}\right)$, nilai budaya $\left(\mathrm{X}_{2}\right)$, dan gaya hidup $\left(\mathrm{X}_{3}\right)$ secara bersama-sama dengan empati lingkungan (Y) ditunjukkan oleh koefisien korelasi jamak yang diperoleh, yaitu $R_{y .123}=0,463$ Hasil uji keberartian koefisien korelasi jamak yang diperoleh, ditunjukkan pada Tabel 14 di bawah ini. 
Tabel 14. Hasil Analisis Uji Keberartian Koefisien Korelasi Jamak antara $\mathrm{X}_{1}$, $\mathrm{X}_{2}$, dan $\mathrm{X}_{3}$ secara Bersama-sama dengan $\mathrm{Y}$

\begin{tabular}{|c|c|c|c|}
\hline \multirow{2}{*}{$\begin{array}{c}\text { Koefisien Korelasi } \\
\left(\boldsymbol{R}_{\boldsymbol{y . 1 2 3}}\right)\end{array}$} & \multirow{2}{*}{$\boldsymbol{F}_{\text {hitung }}$} & \multicolumn{2}{|c|}{$\boldsymbol{F}_{\text {tabel }(3,46)}$} \\
\cline { 3 - 4 } & & $\boldsymbol{\alpha}=\mathbf{0 , 0 5}$ & $\boldsymbol{\alpha}=\mathbf{0 , 0 1}$ \\
\hline 0,463 & $14,2^{* *}$ & 2,67 & 3,91 \\
\hline
\end{tabular}

Tabel 14 di atas memperlihatkan bahwa $F_{\text {hitung }}$ sebesar 14,2 jauh lebih besar daripada $F_{\text {tabel }}$ pada taraf nyata $\alpha=0,01$, sebesar 3,91. Hal ini menunjukkan bahwa koefisien korelasi jamak tersebut sangat berarti (signifikan). Temuan empiris ini sekaligus menolak hipotesis nol yang menyatakan tidak terdapat hubungan positif antara kemampuan kognitif figuratif $\left(\mathrm{X}_{1}\right)$, nilai budaya $\left(\mathrm{X}_{2}\right)$, dan gaya hidup $\left(\mathrm{X}_{3}\right)$ secara bersama-sama dengan empati lingkungan (Y)

\section{HASIL PENGUJIAN HIPOTESIS}

Hasil pengujian hipotesis pada tabel 2 di atas menunjukkan: (1) Hubungan ini ditunjukkan oleh persamaan $\hat{Y}=90,039+0,209 X_{1}$, koefisien korelasi $\mathrm{r}_{\mathrm{y} 1}=0,309$ dan koefisien determinasi sebesar 0,0954; hipotesis nol pertama yang menyatakan terdapat hubungan positif antara kemampuan kognitif dengan empati lingkungan, hal ini berarti terdapat hubungan positif antara kemampuan kognitif dengan empati lingkungan.

Hubungan ini ditunjukkan oleh persamaan

$\hat{\boldsymbol{Y}}=\mathbf{8 0 , 9 0 9}+\mathbf{0 , 2 6 5} \boldsymbol{X}_{\mathbf{2}}$, koefisien korelasi $\mathrm{r}_{\mathrm{y} 1}=0,305$ dan koefisien determinasi sebesar 0,093; hipotesis nol kedua yang menyatakan terdapat hubungan positif antara nilai budaya dengan empati lingkungan ditolak, hal ini berarti terdapat hubungan positif antara nilai budaya dengan empati lingkungan

Hubungan ini ditunjukkan oleh persamaan

$\hat{Y}=88,101+0,204 X_{3}$, koefisien korelasi $\mathrm{r}_{\mathrm{y} 1}=0,281$ dan

koefisien determinasi sebesar 0,0789 ; hipotesis nol ketiga yang menyatakan terdapat hubungan positif antara nilai budaya dengan empati lingkungan ditolak, hal ini berarti terdapat hubungan positif antara nilai budaya dengan empati lingkungan

Hubungan ini ditunjukkan oleh persamaan $\hat{Y}=49,657+0,191 X_{1}+0,167 X_{2}+0,179 X_{3} \quad$ koefisien korelasi $\mathrm{r}_{\mathrm{y} 123}=0,463$ dan koefisien determinasi sebesar 0,2143 ; hipotesis nol keempat yang menyatakan terdapat hubungan posi-tif antara kemampuan kognitif, nilai budaya dan gaya hidup dengan empati lingkungan ditolak, hal ini berarti terdapat hubungan positif antara kemampuan kognitif, nilai budaya dan gaya hidup secara bersama-sama dengan empati lingkungan

\section{KESIMPULAN, IMPLIKASI DAN SARAN \\ A. Kesimpulan}

Berdasarkan hasil pengujian hipotesis, dapat disimpulkan bahwa empati lingkungan masyarakat Kota Surakarta Jawa Tengah dapat ditingkatkan dengan cara mem-pertinggi kemampuan kognitif, nilai budaya dan gaya hidupnya.

\section{B. Implikasi}

Implikasi yang dikemukakan dalam penelitian ini adalah sebagai berikut: Ditemukannya hubungan positif antara kemampuan kognitif, nilai budaya, dan gaya hidup baik secara sendiri-sendiri maupun bersama-sama dengan empati lingkungan melahirkan beberapa implikasi penelitian berikut ini.

Pertama, model konseptual-teoretik yang dicerminkan melalui hubungan hipotetik antar variabel penelitian telah teruji kebenarannya secara empirik. Implikasi teoretiknya ialah bahwa empati lingkungan tidak akan muncul begitu saja, tetapi ditentukan oleh beberapa faktor; dan tiga di antaranya ialah kemampuan kognitif, nilai budaya, dan gaya hidup.

Kedua, implikasi teoretik tersebut selanjutnya melahirkan implikasi kebijakan pokok bahwa untuk meningkatkan empati lingkungan masyarakat dapat diupayakan melalui kemampuan kognitif, nilai budaya, dan gaya hidup. Secara rinci beberapa implikasi kebijakan tersebut diuraikan sebagai berikut:

1. Upaya Meningkatkan Kemampuan Kognitif untuk Meningkatkan Empati Lingkungan dengan tindakan menyadarkan masyarakat secara umum agar tidak membuang sampah sembarangan di segala tempat termasuk ke sungai. Melalui penyuluhan pada secara intensif diupayakan pembuangan limbah pewarna batik benar-benar sesuai dengan baku mutu lingkungan dengan pengontrolan secara kimiawi, biologi dan fisika. yang memadai. Hal ini dilakukan agar tidak berdampak negatif kepada masyarakat

2. Upaya meningkatkan Empati Lingkungan melalui peningkatan Nilai Budaya. Mengubah budaya dan gaya hidup masyarakat agar empati lingkungan. Agar dapat terwujud maka pewaris budaya yang belum beorientasi pada pemeliharaan ligkungan sungai harus di beri pemahaman yang lebih. Sehingga nantinya penerima warisan sosial tersebut sudah terarah. Kalau warisan yang berjalan secara estafet sudah dalam koridor yang baik dan mengacu pada peningkatan empati lingkungan maka budaya yang berkembang di masyarakat secara perlahan-lahan akan membaik.

Upaya Meningkatkan Empati Lingkungan melalui Peningkatan Gaya Hidup. Dengan menerapkan pola gaya hidup yang bersifat positif dapat menghasilkan suatu perubahan

3. lingkungan. Dengan demikian gaya hidup masyarakat sebagai tingkah laku sehari-hari yang mencerminkan aktivitas, Interest, opini, dan etika yang baik ditandai oleh sikap dan nilai yang positif sehingga dapat tercipta gaya hidup yang dapat meningkatkan empati lingkungan

\section{Saran}

\section{Pemerintah}

a. Mengolah limbah yang lebih rentan terjadi di perkotaan, karena banyak IPAL belum memadai dan rusak.

b. Menggalakkan budidaya kebun/ tanaman yang dapat mengurangi kadar racun yang terbuang ke dalam lingkungan. Seperti talas, enceng gondok, pohon kersen adalah jenis tanaman yang diutamakan karena tanaman ini dapat menyerap racun dan logam berat pada pembuangan akhir limbah pada kelompok industri kecil batik. Maka perlu pembuatan pengolahan limbah dengan menerapkan teknologi kimia, fisika dan biologi, hal lain yang dapat dilakukan adalah upaya memberikan himbauan secara umum dengan spanduk-spanduk.

\section{Pemda}

a. Merancang proyek untuk mengatasi dampak negatip B3 limbah batik dengan membangun saluran air khusus limbah.

b. Membudidayakan jenis tanaman yang dapat menyerap racunracun yang dihasilkan oleh B3 inudstri batik sejenis talas atau enceng gondok, seperti disebutkan di atas pada sistem pembuangan dari industri Batik. Tentu saja Pemda harus membangun penampungan limbah beracun dengan tanaman tersebut.

\section{Saran untuk Penelitian Mendatang}

Penelitian mendatang disarankan untuk menggunakan subjek penelitian yang tidak hanya masyarakat berpendidikan rendah, tetapi juga masyarakat berpendidikan tinggi yang tidak berwawasan lingkungan 


\section{DAFTAR PUSTAKA}

A. Robert, Psychology. Boston: Allyn and Bacon, 1992.

AA Prabu Mangkunegara. Perilaku Konsumen. Bandung: PT Eresco, 1988.

Empathy http:/www.6.plala. or.jp./empathy.

Meaning of Emphaty, http:www . infoplease. Com/ipd/A0424447.html.

, True Emphaty http:/www ats.folk.org./tan.htm.

Andreas A. Danandjaja. Sistem Nilai Manajer Indonesia., Jakarta: Pustaka Binaman Presisndo, 1986.

Aronson, Elliot. Social Psychology The Heart and Mind. USA: Harper Collins College Publisher, 1994.

Ashadi. Studi Dekolorisasi Zat Pewarna Tekstil Menggunakan Mikroba. Surakarta: Laboratorium Sentral Universitas Sebelas Maret Sura-karta, 1996.

Benoit, Andre. Pendidikan nilai memasuki tahun 2000. Jakarta: PT Gramedia, 1993.

Bernes, Alison dan Thagard, Paul. Empathy ang Analogy. Waterloo: Ontario, 1997. .http:/waterloo.ca/articles/pages/empathy.html.

Breman, James F. History and System of Psychology dan System Psychology. London: Prentice Hall International INC., 1991.

Busro. Abubakar. Nilai dan Berbagai Aspeknya dalam Hukum. Jakarta: Bhatara, 1989.

Cathelat, Bernard. Socio Life Style Marketing The New Science of Identifying, Classifying and Targeting Consumers Worldwide. Chicago: Probus Publishing, 1993.

Cox, dalam Speight, S.L, Myers, L.J, Cox, C.I, \& Highlen, P.S. A Redefinition of Multicultural Counselin, journal of counseling\&development, 1991.

D. Chiras, Daniel. Enviromental Science Action for a Sustainable Future. California: The Benjamin/Cumming Publishing, 1995.

Dali S Naga. Pengantar Teori Skor pada Pengukuran Pendidikan. Jakarta: Besbats, 1992.

Danandjaja, James Antropology Budaya. Jakarta: PT Raja Grafindo Persada, 1988.

Darmawati, Intan. Perempuan Penyelamat Lingkungan. Jurnal Perempuan judul "Perempuan dan Ekologi”. Jakarta: Yayasan Jurnal Perempuan, 2003.

Darsono, Valentinus. Pengantar Ilmu Lingkungan. Yogyakarta: Universitas Atma Jaya, 1994.

David Loudon dan Albert J Della Bitta. Consumer Behavior Concepts and Application. New York: McGraw Hill Company, 1988.

Davidoff, Linda. Psikologi Suatu Pengantar, terjemahan Mari Juniati. Jakarta: Erlangga, 1991.

Donald Ary dan Lucy C. Jacobs, dan Asghar Razavieh, Introduction to Research in Education. New York: Holt, Rinehart and Winston, 1979.

Edmunds, Stharl dan John Letey, Enviromental Administration. New York: McGraw-Hill Book. Co, 1973.
Efendi, Yusuf. Seni Kriya Batik dalam Tradisi Baru Menghadapi Arus Budaya Global. Makalah. Bandung: 2004.

F Davidooff, Linda. Psikologi Suatu Pengantar. Terjemahan Maria Juniati. Jakarta: Erlangga, 1991.

F Murphy, Robert. Cultural and Social Antrophology An Overture. London: Prentice Hall, 1986.

Ferlald, Dogde. Psycholoy. New Yersey: Prentice Hall, Inc, 1977.

G Benjafield, John. Cognition. New Yersey: Prentice Hall Englewood Cliff, 1992.

Gavin, Helen. The Essence of Cognitive Psychology. New York: Printice Hall Europe, 1998.

Geerzt, Clifford. The Interpretation of Culture Selected Essays.1992.

Goleman, Daniel. Emotional Intelegence, terjemahan T Hermaya. Jakarta: PT Gramedia, 1985.

Henry C Ellis, R. Reed Hunt, Fundamental of Cognitive Psychology. USA: Brown \& Benchmark.

Holahan, Enviromental Psychology. New York: Random House, 1982..

Http: //www.ats.Folk. Org/true.htm.

http://id.wikipedia.org/wiki/Daftar_istilah_lingkungan_hidup.

http://m.kompas.com.

http://ukm.prolh.or.id.

http://www.depkominfo.go.id/2009/07/31/kampung-batik-laweyanlayak-dikembangkan-jadi-kawasan-wisata/.

http://www.indowater.org/?

http://www.indowater.org/?kd=detail\&row=0\&tp=waste\&ktg=\&lat est $=\&$ product $=\&$ kode $=12$.

http://www.tm.Edu/research/cip/hedoisme .htm.

Ibrahim. Contribution of cultural World View to Generic Counseling and Development. Journal of Counseling\&Development.1991.

J.R.E. Kaligis, Pendidikan Lingkungan Hidup. Jakarta: Pusat Penerbibatan Universitas Terbuka, 2003.

James F. Engel, Roger D. Black Wele, dan Paul W Minard, Consumer Behavior. New York: The Dryden Press Harcourt Brace College Publisher. 1995 .

James, Beverly B. Wiggins dan James Vander Zanden, Social Phychology. New York: McGraw Hill, Inc., 1994.

John W.Berry, Ype H. Pooringa, Marshall Segall, Pierre R. Dasen, Psikologi Lintas Budaya Riset dan Aplikasi, terjemahan Edi Suhardono. Jakarta: Gramedia Pustaka Utama, 1999.

Kamisa. Kamus Lengkap Bahasa Indonesia. Jakarta: Gramedia,1986.

Keith Caldwell, Lynton. Environment: A Challengefor Modern Society. New York: The American Museum of Natural History Press, 1970.

Kluckhohn dan Strodbeck dalam Carter. Journal of counseling\&development,1991.

Koentjoroningrat, Rintangan-rintangan Mental dalam Pembangunan Ekonomi di Indonesia. Jakarta: Bhratara, 1995. 
Kotler, Philip. Makerting Management, analisis, Planing, Implementation and Control London: Printice Hall International, 1991.

Kusnoputranto, Haryoto Pengantar Toksikologi Lingkungkan. Jakarta: Dirjen Dikti Dedikbud, 1995.

L. Solso, Robert. Cognitive Psychology. Boston: Allyn and Bacon, 1995.

Leon G Shiffman, Leslie Lazar Kanuk, Consumer Behavior. New Delhi: Pentice Hall of India Private Limited, 1990.

Lewis Glass, Arnold. Cognition. Singapore: MCGraw Hills Book Co, 1988.

Lisa, What is Emphaty ? http;/www.lisa shea.com/lisa base/empathy/html.

M Hidayatuddin. ST, Pengelolaan Limbah Bahan Beracun Berbahaya. Jurnal Nuansa Lingkungan edisi, 2000.

M. Iskandar, Srini. Pendidikan Ilmu Pengetahuan Alam. Jakarta: Departemen Pendidikan dan Kebudayaan Dirjen Dikti, 1997.

M. Keesing, Roger. Cultural Anthropology Acontemporary Perspective, terjemahan Samuel Gunawan. Jakarta: Erlangga, 1989.

Mosak, H.M., dan Dreikus. Current Psychoterapy. Itasca: Peacock, 1973.

Muhadjir, Noeng. Identifikasi Faktor-faktor Opinion Leader Inovatif. Yogyakarta: Rake Sarasin, 2001.

Ndraha, Taliziduhu. Budaya Organisasi. Jakarta: PT Rineka Cipta, 2003.

O Sears, David. Psikologi Sosial, alih bahasa Michael Adriyanto. Jakarta: Erlangga, 1991.

P Dworetzky, John. Psychology. New York: West Publishing Company, 1988.

P. Moran, Aidan. The Psychology of Concentration in Sport. UK \&Francis: Psychology Press, 1996.

P.L Countier, Pemantauan Lingkungan dan Limbah B3 serta Pemanfaatannya dalam Pengelolaan Lingkungan, Jurnal Himpunan Karangan Ilmiah di Bidang Perkotaan dan Lingkungan. Jakarta: Kantor Pengkajian Perkotaan dan Lingkungan, 1993.

Parama Astirin, Okid. Peran Pseudomonas dan Khamir dalam Perbaikan Kualitas dan Dekolorisasi Limbah Cair Industri Batik Tradisional, 2000.

Pedersen et. Al. Counseling Across Cultures (Revised and Expended Edition). Honolulu: university Press of Hawaii, 1981.

Puji. Astuti, P. \& Supadmi, R. MOdel Adsorbsi Filter Ganada untuk Penyempurnaan Pengelolaan Lmbah Cair Effluent Bak Adsobsi IPAL Kampoeng Laweyan Surakarta Ditinjau dari Parameter TSS, COD, Warna \& Bau. Prodi S1 Teknik Kimia Fakultas Teknik USB Surakarta.

Pujiastuti, Peni. Optimasi Peranan "Pseudomonas Aureuginosa dan Saccharomyces Cerevisiae" dalam Penurunan Kandungan Ion Timbal $\left(\mathrm{Pb}^{2+}\right)$, ion Kadmium $\left(\mathrm{Cd}^{2+}\right)$ dan angka BOD pada air Limbah Industri Batik, Jurnal Ilmiah Biologi dan Kesehatan Bio Medika.

Pujiastuti, Peni. Sebaran Karakteristik Air Limbah Industri Batik Sebagai Sumber Utama Pencemaran Tanah Dangkal di Sentra Batik Laweyan Surakarta. Yogyakarta.
R. Ember, Carol. Anthropology. London:Printice Hall International, Inc., 1988.

Republika Newsroom, Pengusaha Batik Butuh IPAL edisi Minggu, 02 Agustus 2009

Republika Newsroom, Pengusaha Batik Butuh IPAL Minggu, 02 Agustus 2009

Richard T Schaefer, Robert P Lamm, Sociology. New York: McGraw-Hill Company, 1989.

Robert L Thorndike dan Elizabeth P Hagen. Measuremant and Evaluation in Psychology and Education. New York: John Wiley \& Sonc, 1977.

Ronald E Smith, Irwin G Sarason, dan Barbara R. Sarason. Psychology The Frontier of Behavior. New York: Harpers \& Row Publishers, 1982.

Ronald E. Smith, Irwin G. Sarason, dan Babara R. Sarason. Psychology The Frontier of Behavior. New York: Harper \& Row Publisher, 1982.

S Feldman, Robert. Social Psychology. New York: The MCGraw Hill Companies, Inc., 1997.

S. Feldman, Robert Understanding Psychology. New York: The McGraw-Hill Companies, Inc., 1997.

Santosa Sukardi, Iman. Era Globalisasi Dunia dan Karakteristik Manusia Indonesia yang Tangguh, Jurnal Psikologi dan Masyarakat. Jakarta: Gramedia Widiasrama, 1993.

Satriago, Handry. Istilah lingkungan untuk Manajemen. Jakarta: Gramedia Pustaka Utama, 1996.

Setiawati, Puspita. Kupas Tuntas Teknik Proses Membatik Dilengkapi Teknik Menyablon. Yogyakarta: Absolut, 2008.

Setyaningsih, Pudji. Penyisihan Warna dan Biodegradasi organik limbah Pewarnaan Batik menggunakan Reaktor Kontinyu Fixed-Bed Anaerob-aerob Master, 2006.

Shelley, Letitia Anne Peplau, David O Sears, Social Phychology. London : Prentice Hall, 1997.

Simuh. Transformasi Tasawuf Islam ke Mistik Jawa. Yogyakarta: Yayasan Bentang Budaya, 1995.

Soetopo. Batik Pendidikan dan Kebudayaan. Jakarta: Balai Pustaka, 1956.

Suciati, Prasetya Irawan, Teori Belajar dan Motivasi. Jakarta: Pusat Antar Universitas Untuk Peningkatan dan Pengembangan Intruksional Dirjen Dikti, 2001.

Sudarno, Seni Lukis Batik. Yogyakarta: 1998.

Sudijono dan Suhartinah. Pasang Surut Batik Tulis Tradisional Bantul. Jakarta: Patra-Widya, 2006.

Sudja,Wasilah Abu. Proses Pembuatan dan Pewarnaan Batik di Indonesia. Bandung: PT Karya Nusantara.1979.

Sudjana. Metode Statistika. Bandung: Tarsito: 1996.

Sudjana. Teknis Analisis Regresi dan Korelasi Bagi Para Peneliti. Bandung: Tarsito, 1992.

Suharsimi Arikunto. Prosedur Penelitian. Jakarta: Rineka Cipta, 2006.

Sumarjan, Selo. Proses Pembudayaan, seminar Lokakarya dengan thema Meningkatkan Usaha Pelembagaan dan Pembudayaan KB di Pedesaan, 1978. 
Suryani, Moch. Lingkungan: Sumberdaya Alam dan Kependudukan dalam Pembangunan. Jakarta: UI Press, 1987.

Sutisna. Perilaku konsumen \&Komunikasi Pemasaran. Bandung: PT Remaja Rosdakarya, 2002.

Thio, Alex. Sosiology An Introduction. New York: Harper Collins Publisher, 1992.

Thomson, Empathy and Consciouness, The American Heritage Dictionary of English Language, Third Edition. Boston: Houghton Miffin, 1992.

Tri Prasetya, Joko. Ilmu Budaya Dasar. Jakarta: PT Rineka Cipta, 1991.

Triguna, Budaya Kerja Menciptakan Lingkungan Kondusive untuk Meningkatkan Produktivitas Kerja (Jakarta: PT Golden Terayon Press, 2000.

Tudor, Mary. Child Development. New York: McGraw Hill Book Company, 1981.

Turk, Jonathan. Environmental Science. New York: Sauders College Publishing, 1984.

W Vander Zanden, Jame.s Sosilology The Core. New York: McGraw Hill, Inc., 1996.

Western, Drew. Psychology Mind and Brain \& Culture. New York: John Wiley \& Sons, Inc., 1996.

Winardi, J. Motivasi \& Pemotivasian dalam Manajemen. Jakarta: PT Raja Grafindo Persada, 2001.

Wirawan Sarwono, Sarlito. Psikologi Sosial Individu dan Teori Psikologi Sosial. Jakarta: Balai Pustaka, 1999.

Yusuf, Yusmar. Psychologi antar Budaya. Bandung: Remaja Rosdakarya, 1991. 